\title{
Compare emotion recognition dimensions in people with antisocial and obsessive-compulsive personality disorders and those with normal personality
}

\author{
Monir Jamali ${ }^{1}$, Farzin Yaghmaee ${ }^{2}$, Parviz Sabahi ${ }^{3}$, Imanollah Bigdeli ${ }^{4}$ \\ 1- Master of Cognitive Psychology, Semnan University, Semnan, Iran. \\ 2- Associate Professor, Department of Electrical \& Computer Engineering, Semnan University, Semnan, Iran. \\ 3- Assistant Professor, Department of Clinical Psychology, Semnan University, Semnan, Iran (Corresponding \\ Author). E-mail: p_sabahi@semnan.ac.ir \\ 4- Professor, Department of Clinical Psychology, Ferdowsi University of Mashhad, Mashhad, Iran.
}

Received: 09/12/2019

Accepted: 04/03/2020

\begin{abstract}
Introduction: Emotion recognition is an essential ability to understand others' behavior. Emotions can be recognized through facial expression, voice, and gestures.

Aim: This study aims to compare emotion recognition dimensions in people with antisocial (ASPD) and obsessive-compulsive personality disorders (OCPD) and those with normal personality.

Method: The statistical population of this descriptive, causal-comparative research included all female students of Ferdowsi University of Mashhad in the academic year 2016. A total of 400 students were randomly selected to fill out Millon Clinical Multiaxial Inventory, 3rd edition (MCMI-III). Then, a total of 30 students were assigned to each group based on the inclusion criterion. The participants took part in facial, vocal, and somatic emotion recognition and theory of mind tests. Data were analyzed using univariate and multivariate analysis of variance.

Results: Results showed a significant difference between ASPD and OCPD groups for vocal anger emotion arousal $(\mathrm{p}=0.028)$. The results also showed a significant difference between OCPD and normal personality groups in terms of neutral emotional intensity $(\mathrm{p}=0.049)$. Moreover, a significant difference was observed between ASPD and normal personality groups for somatic emotion recognition in two states of happiness $(\mathrm{p}=0.004)(\mathrm{p}=0.001)$, and between OCPD and normal personality groups in one state of happiness $(\mathrm{p}<0.05)$.

Conclusion: Individuals with ASPD showed better performance in recognizing somatic emotion, which provides a theoretical ground for new therapeutic methods. However, further studies are required to recognize emotion using different methods (voices, body movements, etc.) in clinical samples.
\end{abstract}

Keywords: Emotion recognition, Antisocial personality disorder, Obsessive- compulsive personality disorder, Normal

\footnotetext{
How to cite this article : Jamali M, Yaghmaee F, Sabahi P, Bigdeli I. Compare emotion recognition dimensions in people with antisocial and obsessive-compulsive personality disorders and those with normal personality. Shenakht Journal of Psychology and Psychiatry. 2020 ; 7 (1): $57-$
} 77 .URL: http://shenakht.muk.ac.ir/article-1-711-fa.pdf

Copyright $($ C 2018 the Author (s). Published by Kurdistan University of Medical Sciences. This is an open access article distributed under the terms of the Creative Commons Attribution-Non Commercial License 4.0 (CCBY-NC), where it is permissible to download, share, remix, transform, and buildup the work provided it is properly cited. The work cannot be used commercially without permission from the journal. 


\title{
مقايسه ابعاد بازشناسى هيجان در افراد با نشانهاى اختلال شخصيت ضداجتماعى، اختلال شخصيت وسواسى و بهنجار
}

\author{
منير جمالى '، فرزين يغمايى'، يوويزصباحى ‘ ايمان اله بيعدلى \\ ا. كارشناس ارشد روانشناسى شناختى، دانشگاه سمنان، سمنان، ايران. \\ r. دانشيار، گروه برق و كامييوتر، دانشگاه سمنان، سمنان ، ايران.

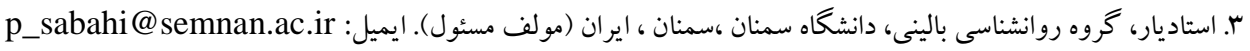

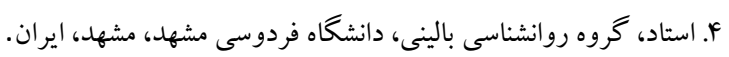 \\ تاريخ هذيرش مقاله:

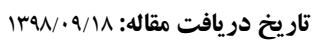

جكکبه

مقدمه: توانايى بازشناسى هيجان، براى درك رفتار شخص مقابل ضرورى است و بازشناسى هيجان مىتواند از جهره، صدا و حر كات بدن انجام يذيرد.

هدف: هدف يثزوهش، مقايسه ابعاد بازشناسى هيجان در افراد با نشانهاى اختلال شخصيت ضداجتماعى و وسواسى و عادى بود. روش: روش ئزوهش توصيفى از نوع على مقايسهاى بود. جامعه آمارى يثزوهش را تمامى دانشجويان دختر دانشگاه فردوسى در سال

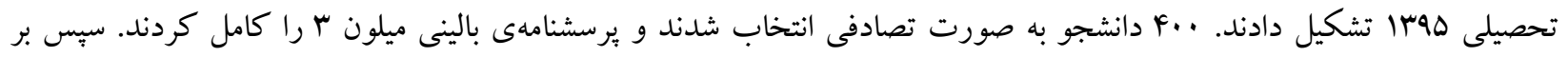

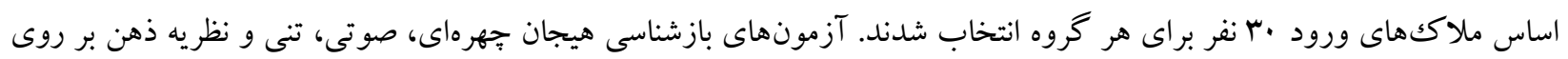

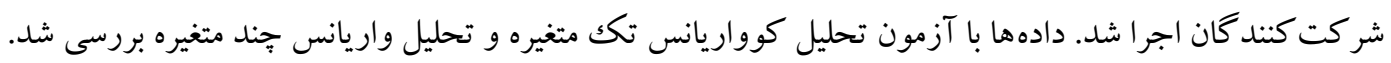
يافتها: نتايج نشان داد بين گروه شخصيت ضداجتماعى و شخصيت وسواسى در امتيازدهى برانگيختكى هيجان صوتى خشم

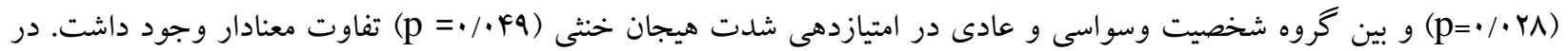

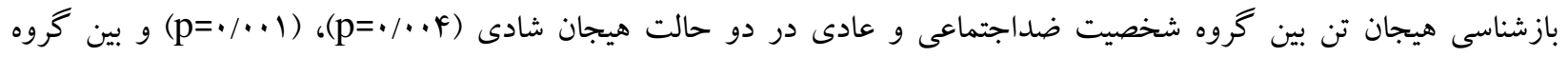

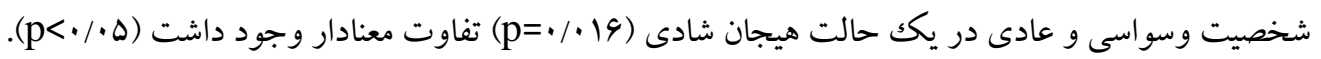
نتيجه كيرى: بر اساس نتايج به دست آمده، افراد با ويز گى هاى شخصيت ضداجتماعى در بازشناسى هيجان تن عملكردى بهترى دارند و مى توان ييشزمينهاى نظرى براى شيوههاى جديد درمانى را مطرح كرد. البته تحقيقات بيشترى در بازشناسى هيجان به روشهاى

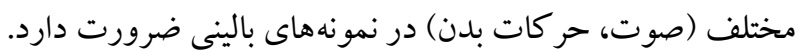
كليدوازهها: بازشناسى هيجان، اختلال شخصيت ضد اجتماعى، اختلال شخصيت وسواسى، بهنجار 
خوردن و انواع اختلالات شخصيت (اشنايدر، كريستنس،

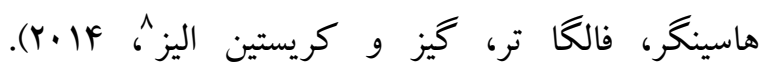
بزوهش هاى مختلف نشان داده است، افراد مبتلابه اختلال شخصيت ازنظر كاركرد شناختى دجار مشكل هستند

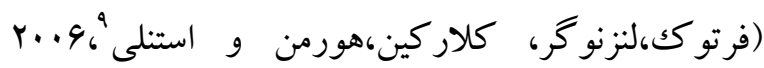

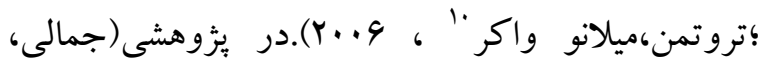

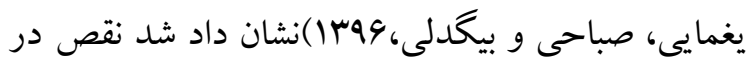
توجه انتخابى با بروز نشانهاى اختلال شخصيت مرتبط

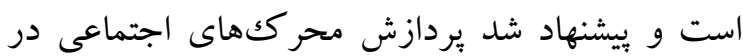
اختلال شخصيت ضداجتماعى " و اختلال شخصيت

$$
\text { وسواسى " مورد بررسى قرار گيرد. }
$$

طبق ويرايش بنجم راهنماى آمارى و تشخيصى اختلالات

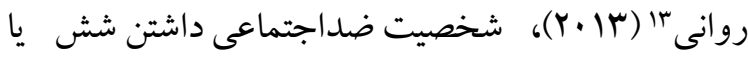
بيشتر از هفت صفت شخصيتى مرضى كه شامل :

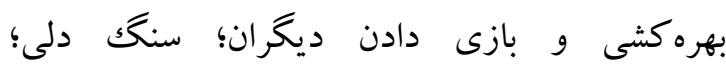

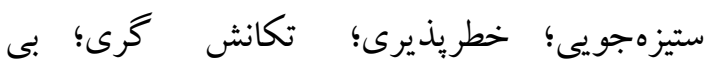
مسئوليتى؛ جسور و نترس بودن تعريفشده است.

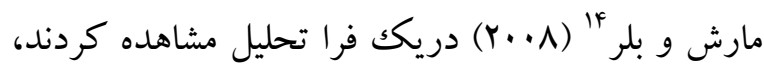
افرادى كه علائم رفتار ضداجتماعى را دارند، اغلب در شناسايى هيجان جهره نقص دارند و در شناسايى هيجان ترس ضعيفتر عمل مى كنند؛ كه مىتواند دليل آن بد

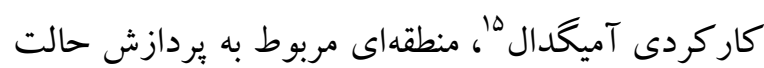
ترس باشد. بازشناسى هيجان جهره بر روى IYV زندانى

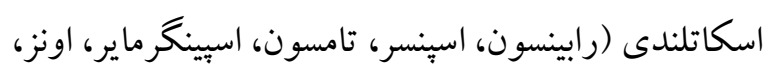

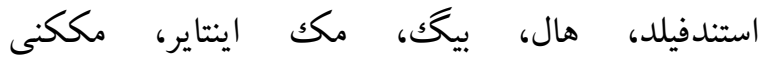

\footnotetext{
8- Schneider S, Christensen A, Häußinger F B, Fallgatter A J, Giese M A, Christine Ehlis A

${ }^{9}$ - Fertuck E A, lenzenweger M F, clarkin J F, Heormenn s \& Stanley B

${ }^{10}$ - Tromtman H, MC Millan A \&Walker E.

${ }^{11}$ - Antisocial personality disorder

${ }^{12}$ - Obsessive-compulsive personality disorder

${ }^{13-}$ Diagnostic and statistical manual of mental disorders DSM

${ }^{14}$ - Marsh and Blair

15- Amygdala
}

\section{مقدمه}

شناخت اجتماعى' فرايندى است در يكك دامنه شناختى خاص انسان؛ شامل اعمال ذهنى كه زمينه رفتار و تعامل اجتماعى را براى بِاسخ به مشكلات اجتماعى فراهم

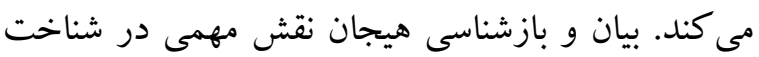
اجتماعى دارد. زمانى كه هيجانات ابرازشده توسط ديخران شناسايى مىشود، نشانهايى دربارهُ حالات ذهنى افراد به دست مى آيد. علاوه بر اين بهمنظور تفسير

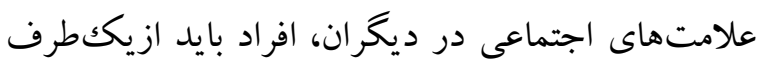
توانايى همدلى و از طرف ديخر داراى توانايى استفاده از يك جهارجوب مرجع؛ شامل نظريههاى در مورد رفتار ديخران باشند. بهعنوانمثال ما با در نظر گرفتن افكار و هيجانات ديخران، به انجام رفتارهايى خاص دست

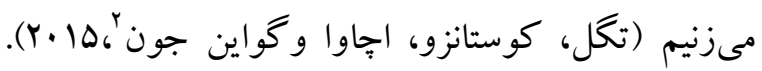

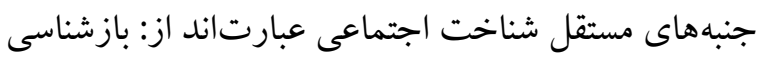
هيجان"، سبك اسنادى " و نظريه ذهن (اسجيماسنكى، ديويد، راسلر وهاكرهّ؛ +1 +r). بازشناسى هيجان شخص

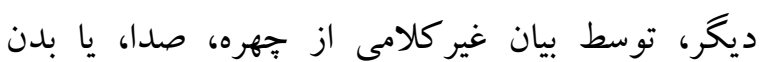
صورت مى گيرد و توانايى كليدى در تعاملات اجتماعى و بيش شرطى براى دركك و بيشبينى و واكنش مناسب به

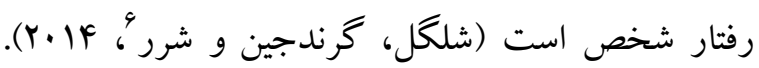
نقص در بازشناسى هيجان با ضعف مهارت هاى اجتماعى در ارتباطات و عملكرد بين فردى و رفتار اجتماعى

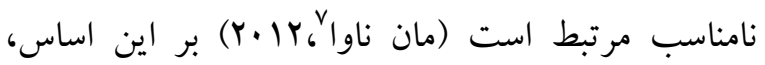
نقص در بازشناسى هيجان در انواع مختلف اختلالهاى روانى قابلمشاهده است؛ مانند اختلالات خلقى، اختلال

\footnotetext{
1- Social cognition

2- Ruiz-Tagle A, Costanzo E,De Achával D,Guinjoan S

3 - Emotion recognition

${ }^{4}$ - Attribution styles.

5 - SchimanskyJ D, Rossler w n \& Haker H.

${ }^{6}$ - Schlegel K, Grandjean D \& SchererK R

- Mannava S
} 


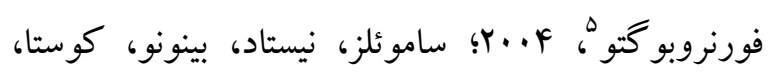

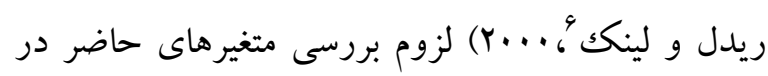
يثزوهش در اختلال شخصيت وسواسى احساس مى شود. تحقيقات عصب زيستى بر ادراك هيجانات جهره نشان

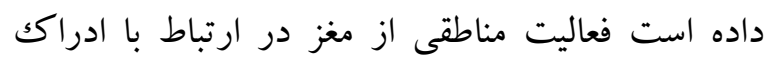

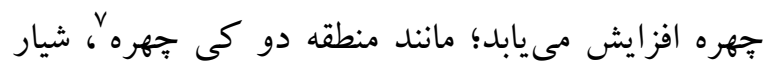

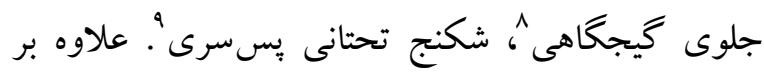
اين گزارش شده حالات هيجانى جهره، فعاليت عصبى رانس بهصورت شبكهاى توزيعشده ازجمله آميخدال، اينسولا 'ا'،

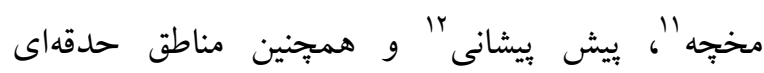
ييشانى ب" مغز راهاندازى مئى كند (اشنايدر و همكاران،

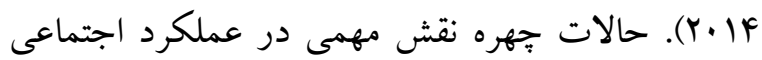
انسان بازى مى كند، اما تحقيقاتى نشان داده، دركى هيجانات جهره بهطور قابل توجهى تحت تأثير حالات كل

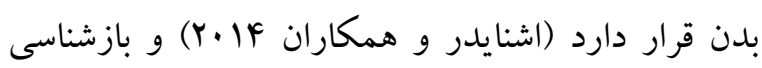

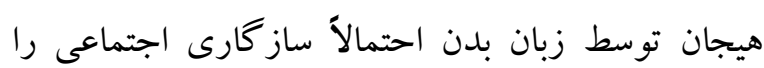

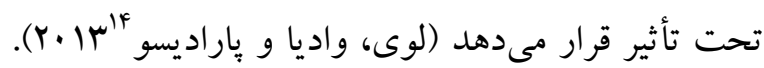
بازشناسى هيجان را مى توان از بسيارى از منابع ازجمله صدا، جشمها، زست بدن و جهره انجام داد. در حال حاضر بسيارى از روشهاى بازشناسى هيجان تنها از يكك

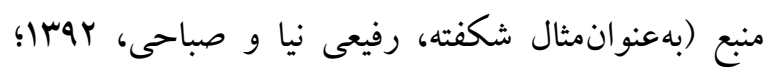
نجاتى و همكاران سوس|) استفاده كردهاند. با توجه به اين كه ابراز هيجانات افراد در هرلحظه تغيير مى كند، بررسى از يكى روش واحد براى بردازش بازشناسى

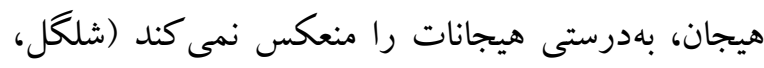

\footnotetext{
5 - Albert,mania, Forner, Bogetto

${ }^{6}$ - Samuels, Nestadt, Bienvenu, Costa, Riddle, Liang, Cullen

7. The fusiform face area

${ }^{8}$ - Superior temporal sulcus

9 - Inferior occipital gyrus

${ }^{10}$ - Insula

${ }^{11}$ - The cerebellum

12. Prefrontal

13- Orbitofrontal

${ }^{14}$ - Loi, Vaidya, \& Paradiso
}

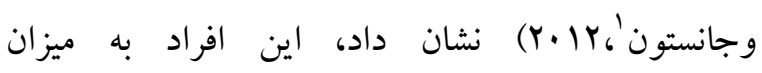
قابلتوجهى، در بازشناسى هيجانات، خشم، ترس، غم و نفرت ضعيف بودند. در ميان تعداد زيادى از مؤلفههاى روانشناختى مؤثر در بروز يا بهبود اختلال وسواسى جبرى مى توان به هيجان اشاره كرد (كاستر، ليمن رادت

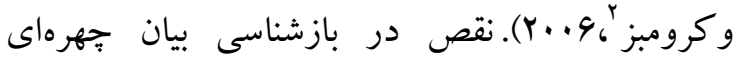
هيجان سازماى است كه مئواند در تشديد علائم اختلالات وسواس فكرى عملى نقش لنش بسزايى داشته باشد (اميرى، قاسم بور، فهيمى،

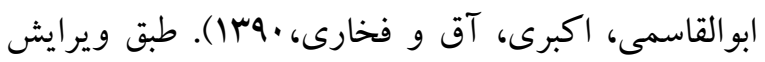
ينجم راهنماى آمارى و تشخيصى اختلالات روانى (Y. (Y. )، شخصيت وسواسى داشتن سه يا بيشتر از جهار صفت شخصيت مرضى، شامل: كمال طلبى سخت گير انه؛ درجا ماندگى؛ اجتناب از صميميت؛ هيجان بذيرى محدود كه يكى از آنها مىبايست كمال طلبى سخت گير انه باشد، تعريف شده است. در فرا تحليلى كه

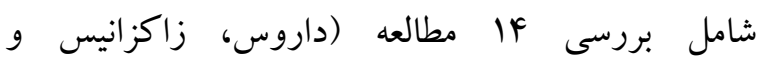

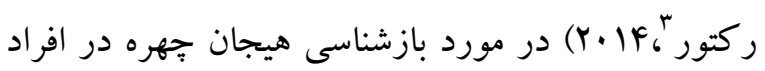
وسواس-جبرى انجام شد. بيماران اختلال وسواسجبرى "بهطور كلى نسبت به گروه كنترل دقت كمترى در بازشناسى حالات هيجانى جهره به خصوص در بازشناسى هيجانات منفى ازجمله نفرت و خشم داشتند. به علت اينكه ئزوهشى در مورد بازشناسى هيجان و نظريه ذهن

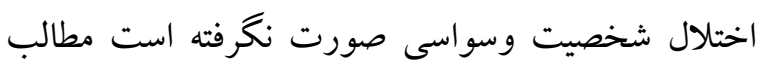
ذكرشده مرتبط با اختلال وسواس-جبرى بود و به دليل همبودى بالاى اين دو اختلال (البرت، ماينا،

1- Robinson, Spencer, Thomson, Sprengelmeyer, Owens, Stanfield, McKechanie

2- Koster. Leyman Raedt R,\& Crombez G

3 - Daros, Zakzanis, \& Rector

4- Obsessive-compulsive disorder 
مطرح كرد. مىتوان ابزارهايى ساخت كه با دقت بيشترى

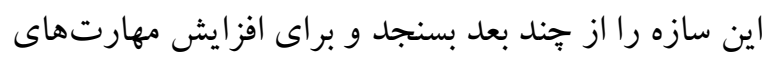
بازشناسى هيجان مورد استفاده قرار گيرد.

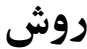
يزّوهش حاضر توصيفى، از نوع على - مقايسهاى است. جامعة آمارى إزوهش را كلئ دانشجويان دختر دانشخاه فردوسى شهر مشهد كه در سال تحصيلى هوبا اين دانشگاه مشغول به تحصيل بودند تشكيل مى مدادند. ابتدا از

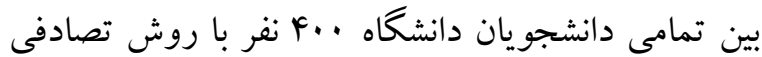
ساده انتخاب و با توجه به ملاككهاى ورود و و و خروج .q نفر انتخاب شدند. ملاككهاى ورود در در يزوهش حاضر عبارت بودند از: كسب نمره برش (بر اساس انحراف از ميانگين) در آزمون ميلون

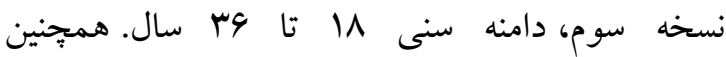
ملاككهاى خروج در ئزوهش حاضر شامل:داشتن هر گونه مشكلات حسى و حركتى، سابقه مصرف هر گونه داروى روانيزشكى در رابطه با اختلالات سايكوتيكك، خلقى و اضطرابى، سابقه سوءمصرف مواد بود. همجنين بهمنظور كنترل اختلالات همبود از افرادى كه ملاكك ورود به يُوهش را داشتند مصاحبه بالينى ساختار يافته بر مبناى راهنماى تشخيصى و آمارى اختلالات روانى به عمل آمد. در اين يُوهش، ابتدا نرمافزار يرسشنامهُ جند محورى بالينى ميلون

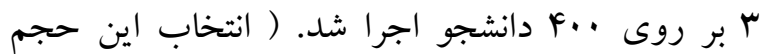

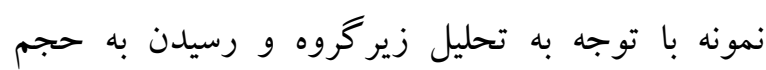
مطلوب در هر گروه بود ) از آنجاكه تعيين حجم نمونه در رابطه با طرحهاى على_مقايسهاى حداقل بين ها تا •ب نفر

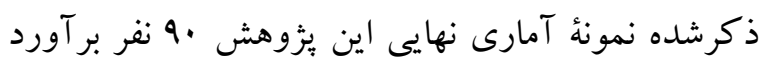

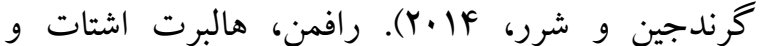

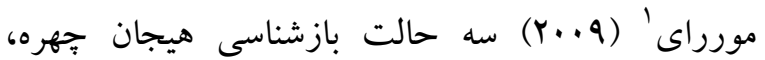
شنيدارى و بدن را در افراد مسن بررسى كردند. افراد مسن مشكلات بيشترى در شناسايى هيجان مثبت (شادى) و منفى (خشم، غم) و حالات شنيدارى و بدنى نسبت به جوانان نشان دادند. توانايى (انظريه ذهن) دركك اين موضوع كه ديخران واجد حالتهاى ذهنى هستند كه مىتواند متفاوت باحالتهاى ذهنى خود فرد يا واقعيت باشد و اينكه انسان بهوسيله حالتهاى ذهنى درونى مانند

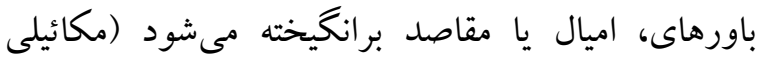
و آدينه، (هبا). نجّاتى، ناصريور، ذبيح زاده و رشيدى (سوسا)در طى بررسى نظريه ذهن و همدلى محكومين داد گاههاى كيفرى با افراد عادى به اين نتيجه رسيدند ،عملكرد محكومين دادگاههاى كيفرى در آزمون ذهنخوانى معنادارى پايينترى از همتايان عادى آنها داشتند. در بثروهشى توسط درويشى، على لو، بخشى بور، فرنام و بهرام خانى(Yar|) بر روى افراد وسواسى -جبرى و بهنجار صورت گرفت، افراد مبتلابه وسواسى -جبرى نسبت به كروه بهنجار در تكاليف نظريه ذهن عملكرد ضعيفترى داشتند. مسئلهى يزوهش حاضر اين است كه آيا افراد با نشانه هاى اختلال شخصيت ضداجتماعى و شخصيت وسواسى در بازشناسى هيجان در ابعاد مختلف و نظريه ذهن با افراد بهنجار تفاوت دارند يا خير؟ از آنجا يافتهاى برخى از يُوهشها متفاوت است و در ايران نيز

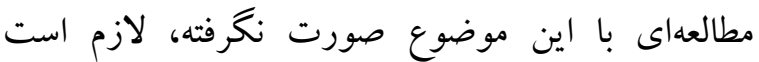
بررسىها در مورد بازشناسى هيجان در ابعاد مختلف

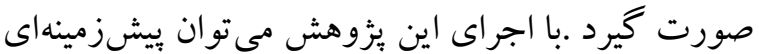
نظرى براى طرح شيوههاى جديد درمانى و مشاوره را

\footnotetext{
1- Ruffman, Halberstadt, \& Murray
} 


$$
\text { آزمون برابر با NA • است. }
$$

\section{آزمون ذهنخوانى از طريق جشمها (بارون-كوهن):}

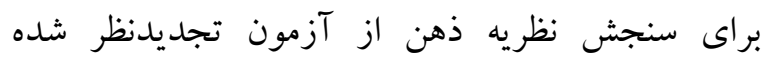
ذهنخوانى از طريق جشمها (بارون- كوهن (Y...) استفاده شد. فرم تجديدنظر شده اين آزمون (فرم وب مادهاى) شامل عكسهايى از ناحيه جشم هنرييشهاى زن و مرد بود. با هر ماده جهار توصيف حالت ذهنى (يكك حالت هدف و سه حالت انحر افى با همان ارزش هيجانى) ارائه مىشد. تنها با استفاده از اطلاعات بينايى از ياسخدهند گان خواسته مىشد كلمه ايى كه بهترين توصيف كننده فكر يا احساس صاحب جشمها است را انتخاب كنند. ضريب آلفاى كرونباخ اين آزمون IV/ • و يايايى آن به روش كودر -ريجاردسون 99/ • بهدست آمده است (شكفته و همكاران).

Tآزمون بازشناسى هيجان جهرهاع: اين آزمون شامل عكس سياه و سفيد از هيجانات جهرهاى است كه در سال 19V9 بهوسيله اكمن و فرايزن (19V9) ساخته و ولهيك جمع آورىشده است (موسويان و هاديانفرد،وبا1). ضريب بايايى به روش باز آزمايى اين آزمون در فاصله

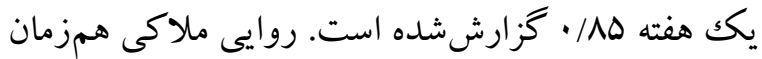
اين آزمون با آزمون حافظه وكسلر \&/×، برسشنامه

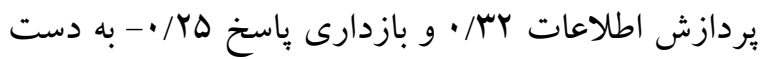
آمد (نجاتى وهمكار ان، بrar). آزمون صداهاى عاطفى مونترال (MVA) :آزمون صداهاى عاطفى مونترال •9 ابراز عاطفى غير كلامى "َ كه شامل هشت هيجان خشم، تنفر، ترس، درد، غم، حيرت، شادى و لذت (بعلاوه خنثى) است. اين آزمون توسط

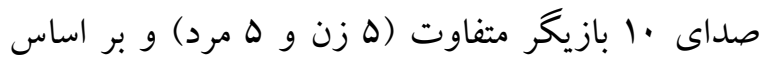

${ }^{2}$ - The Montreal Affective Voices task

3. Brust
شد كه در سه گروه.r نفرى اختلال شخصيت ضداجتماعى و اختلال شخصيت وسواسى و عادى جاى كرفتند. بيش از اجرا بهمنظور رعايت اصول اخلاقى

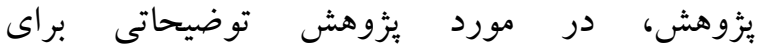
شر كت كنند كان ارائه شد و از آنها رضايت آكاهانه اخذ

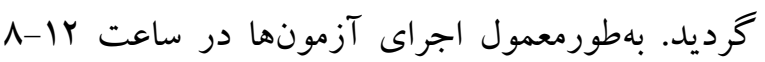
صبح و ا تا ه بعدازظهر در سه روز بهصورت متوالى انجام شد؛ و براى هر آزمودنى حدود ا ساعت زمان در هر جلسه، براى اجراى آزمونها صرف شد، در اين

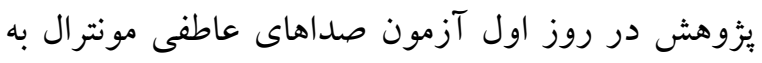
همر اه بخش بازشناسى حر كات بدن حالت يكيار جه نور. روز دوم، آزمون نظريه ذهن و حر كات بدن قطعه نور. روز سوم، آزمون بازشناسى هيجان جهره و حر كات بدن نقطه نور اجرا شد. براى بررسى فرضيه آناى بزوهش از

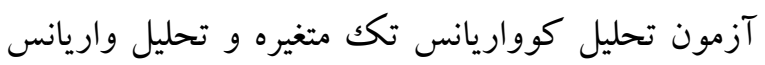
جند متغيره استفاده شد.

ابزار

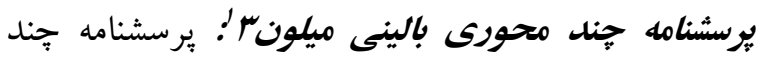

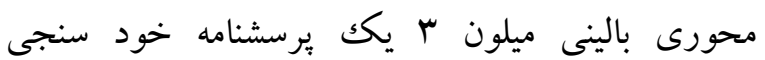

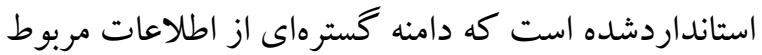
به شخصيت، ساز گارى هيجانى و نگرش مراجع به آزمون

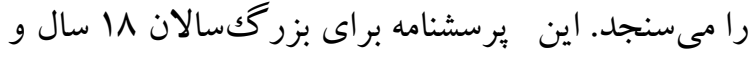
بالاتر كه دست كم توانايى خواندن آنان تا سطح كلاس هشتم است طراحىشده است. نسخه سه ميلون IVD سؤال در Y مقياس جداكانه داشته و براى اندازهگيرى ميزان بايايى ميلون و همكارانش (1994؛ به نقل از آشتيانى و

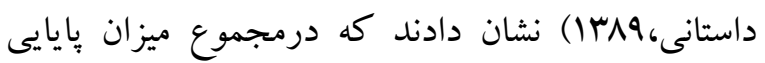

\footnotetext{
${ }^{1}$ - Millon Clinical Multiaxial Inventory (MCMI-III)
} 
وتحليل دادهها نمرات ^ آزمودنى به علت كامل نكردن آزمونها از اين تعداد حذف شدند. بدين ترتيب rV نفر اختلال شخصيت ضداجتماعى، Y نفر اختلال شخصيت وسواسى و هץ نفر بهنجار در نظر گرفته شد. براى تجزيه و تحليل اطلاعات از آمار توصيفى (ميانگين، انحراف

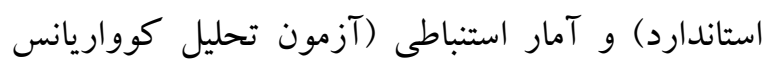
تكك متغيره و تحليل واريانس جند متغيره) استفاده شد. در اين بخش ابتدا در جدول زير ميانگين و انحر اف معيار در سه گروه در بازشناسى هيجان صوت آورده شده است.
ميزان رتبهبندى ارزش'، برانخيختخى ' و شدت ' هيجان

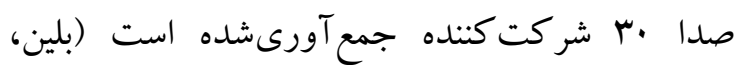

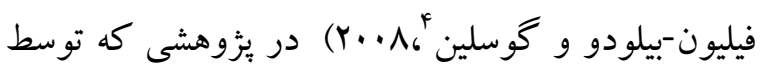

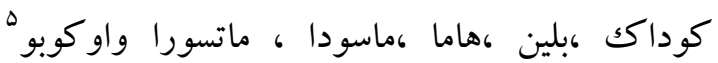

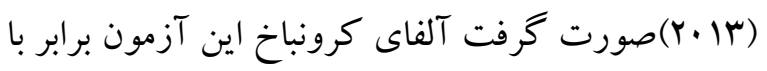

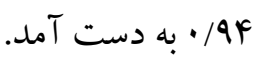

درك /براز ايستا و يويا هيجان بلن توسط نمايش

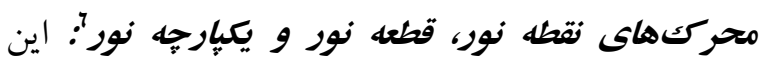
آزمون شامل فيلمها و تصاوير است كه در سال F...F

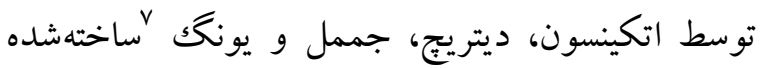
است. اين دادهها ه حالت هيجانى غم، شادى، ترس، تنفر

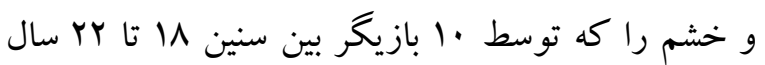

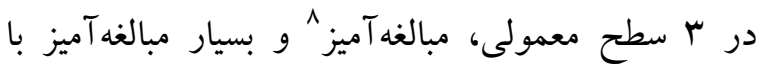
جهره بوشيده، در دو مجموعه يكسان نقاط (قطعه) نورانى و يكهارجه نورانى ايجاد شد. اتكينسون و همكاران در

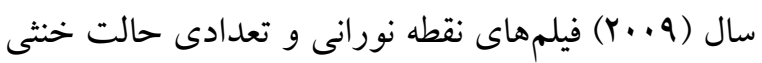
(بهعنوانمثال: خم شدن، جهش، ضربه زدن) را به

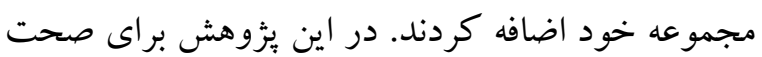

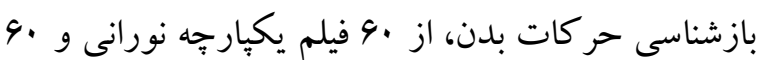
فيلم قطعه نورانى و .4 فيلم نقطه نورانى استفاده شد.

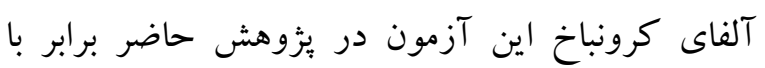
1/ • •به دست آمد.

يافته ها كل نمونهُ موردمطالعه ·ه نفر بود؛؛ كه هنگام تجزيه

1- Valence

${ }^{2}$ - Arosul

3 - Intensity

${ }^{4}$ - Belin, Fillion-Bilodeau, \& Gosselin

5 - Koeda, Belin, Hama, Masuda, Matsuura and Okubo

${ }^{6}$ - Emotion perception from dynamic and static body expressions in point-light and full-light displays

7 - Atkinson, Dittrich, Gemmell, \& Young

${ }^{8}$ - Exaggeration 
جدول ا ميانكين و انحراف معيار بازشناسى هيجان صوت در سه تروه

\begin{tabular}{|c|c|c|c|c|c|c|c|c|c|}
\hline انحر اف & ميانكين & كروه & حالت & هيجان & انحر اف & ميانكين & كروه & حالت & هيجان \\
\hline $\mid r / a r$ & $\Delta \Lambda / \cdot 1$ & ضداجتماعى & \multirow[t]{3}{*}{ شدت هيجان } & \multirow[t]{9}{*}{ درد } & $\mid Q / F r$ & $\Delta V / \& \varphi$ & ضداجتماعى & \multirow[t]{3}{*}{ شدت هيجان } & \multirow[t]{9}{*}{ خشم } \\
\hline Tr/Tr & $\Delta V / V$ & وسواسى & & & YI/FY & $9 \Delta / \mathrm{VV}$ & وسواسى & & \\
\hline IG/AF & GY/AY & عادى & & & $19 / 09$ & GV/VT & عادى & & \\
\hline $\mid r / f r$ & TF/OF & ضداجتماعى & \multirow[t]{3}{*}{ ارزش هيجان } & & $11 / Y \Lambda$ & $r Y / 9 \Delta$ & ضداجتماعى & \multirow[t]{3}{*}{ ارزش هيجان } & \\
\hline $\mid V / 91$ & YY/YY & وسواسى & & & $I V / \Delta V$ & $r \cdot / \wedge \Delta$ & وسواسى & & \\
\hline$|r / 9|$ & $r q / 9 F$ & عادى & & & $\mid F / 9 F$ & $r r / \Delta V$ & عادى & & \\
\hline $11 / .9$ & $F \cdot / M V$ & ضداجتماعى & \multirow{3}{*}{ برانخيختخى } & & $r I / r q$ & $M F / 9$. & ضداجتماعى & \multirow{3}{*}{ برانگيختگى } & \\
\hline YY/VG & $F r / Y I$ & وسواسى & & & $r \Delta / G Y$ & FN/GF & وسواسى & & \\
\hline $19 / 49$ & FV/AG & عادى & & & $r Y / Y q$ & $k 9 / 9 \mathrm{~V}$ & عادى & & \\
\hline$Y Y / \Delta V$ & $r 4 / 9 r$ & ضداجتماعى & \multirow{3}{*}{ شدت هيجان } & \multirow[t]{9}{*}{ خنثى } & $1 r / \cdot 9$ & $V Y / F A$ & ضداجتماعى & \multirow[t]{3}{*}{ شدت هيجان } & \multirow[t]{9}{*}{ شادى } \\
\hline$r \Delta / M$ & MF/YY & وسواسى & & & $19 / \Delta r$ & $99 / \cdot 1$ & وسواسى & & \\
\hline$M I / 9 V$ & $\Delta \cdot / V V$ & عادى & & & $r 1 / 9 V$ & $99 / M^{M F}$ & عادى & & \\
\hline $19 / 10$ & TI/AD & ضداجتماعى & \multirow[t]{3}{*}{ ارزش هيجان } & & $11 / \wedge \Delta$ & $V Y / 90$ & ضداجتماعى & \multirow[t]{3}{*}{ ارزش هيجان } & \\
\hline $11 / 99$ & Tr/FY & وسواسى & & & $19 / \mathrm{K}$ & $V \cdot / A r$ & وسواسى & & \\
\hline$r \cdot / \Delta \Delta$ & rg/V. & عادى & & & $\mid f / q$. & $V \cdot / r q$ & عادى & & \\
\hline $1 N / r \Delta$ & 1N/94 & ضداجتماعى & \multirow{3}{*}{ برانگيختگى } & & Yr/Tr & $\Delta V / Y r$ & ضداجتماعى & \multirow{3}{*}{ برانگيختىى } & \\
\hline$|N| \cdot r$ & $19 / 19$ & وسواسى & & & $19 / \mathrm{V}$ & $\Delta Q / \Delta r$ & وسواسى & & \\
\hline$r \Delta / V q$ & $r \Psi / Y V$ & عادى & & & $r 1 / T q$ & $\Delta \Lambda / ৭ \Delta$ & عادى & & \\
\hline$r Q / \Gamma \wedge$ & $F 1 / 99$ & ضداجتماعى & \multirow[t]{3}{*}{ شدت هيجان } & \multirow[t]{9}{*}{ تعجب } & $|r / A|$ & $90 / 1 V$ & ضداجتماعى & \multirow[t]{3}{*}{ شدت هيجان } & \multirow[t]{9}{*}{ غم } \\
\hline$r r / q q$ & $F \mid / \Delta \Lambda$ & وسواسى & & & YI/Yr & $9 V / Y 1$ & وسواسى & & \\
\hline YA/VY & FG/FY & عادى & & & IY/AS & $v r / 1$ & عادى & & \\
\hline$r \& / .$. & re/vV & ضداجتماعى & \multirow[t]{3}{*}{ ارزش هيجان } & & $\mid r / r$. & rr/qr & ضداجتماعى & \multirow[t]{3}{*}{ ارزش هيجان } & \\
\hline Yr/VF & rQ/rq & وسواسى & & & $r \cdot / \cdot r$ & $r \cdot / \cdot F$ & وسواسى & & \\
\hline$r \cdot 199$ & $f \cdot 191$ & عادى & & & Yr/VD & rr/VD & عادى & & \\
\hline$r F / F q$ & $r q / 4$. & ضداجتماعى & \multirow{3}{*}{ برانگيختخى } & & $r \cdot / 9 V$ & $14 / 90$ & ضداجتماعى & \multirow{3}{*}{ برانگيختخى } & \\
\hline rV/VD & MI/VD & وسواسى & & & rr/VA & $\Delta r / q V$ & وسواسى & & \\
\hline$r \cdot / V q$ & rr/90 & عادى & & & $19 / \pi Y$ & $\Delta V / l$. & عادى & & \\
\hline$|r /| V$ & $9 Y / 9 D$ & ضداجتماعى & \multirow[t]{3}{*}{ شدت هيجان } & \multirow[t]{6}{*}{ ترس } & $\mid N / F q$ & $k q / Y V$ & ضداجتماعى & \multirow[t]{3}{*}{ شدت هيجان } & تنفر \\
\hline $19 / 1$. & Gr/AV & وسواسى & & & $r r / Q \Lambda$ & $\Delta I / V F$ & وسواسى & & \\
\hline $10 / 1 Y$ & GV/Dr & عادى & & & 19/94 & $9 \cdot 19$. & عادى & & \\
\hline $\mid F / \pi \Delta$ & YN/MA & ضداجتماعى & ارزش هيجان & & $11 / 91$ & YY/G) & ضداجتماعى & ارزش هيجان & \\
\hline $11 / 91$ & $r Y / .9$ & وسواسى & & & $1 F / 19$ & $19 / \Gamma V$ & وسواسى & & \\
\hline $19 / 1 \mathrm{r}$ & $r V / 19$ & عادى & & & $10 / r$. & $r Q / A r$ & عادى & & \\
\hline$r \cdot / \cdot \Lambda$ & $F \wedge / F \Lambda$ & ضداجتماعى & بر انگيختخى & & $M / V F$ & $M T / Q T$ & ضداجتماعح & تخىى & \\
\hline
\end{tabular}




\begin{tabular}{|c|c|c|c|c|c|c|c|c|c|}
\hline$r M / \Delta q$ & FV/AT & وسواسى & \multirow[t]{2}{*}{ هيجان } & & $r M / M$ & $\mathrm{rV} / \mathrm{\Delta}$. & وسواسى & \multirow[t]{2}{*}{ هيجان } & \\
\hline MN/Dr & $\Delta \cdot|\Lambda|$ & عادى & & & $19 / \mathrm{V} \mid$ & $f \cdot / \Delta \Delta$ & عادى & & \\
\hline YI/99 & $M T / Q \Delta$ & ضداجتماعى & \multirow{3}{*}{ هيجان } & \multirow[t]{3}{*}{ لذت } & $r \cdot / l F$ & $F F / F Y$ & ضداجتماعى & \multirow[t]{3}{*}{ شدت هيجان } & \multirow[t]{6}{*}{ لذت } \\
\hline$r V / G \Lambda$ & rV/VG & وسواسى & & & YN/AF & $\Delta \cdot / A F$ & وسواسى & & \\
\hline$r F / \cdot r$ & $r q / 9$. & عادى & & & $Y F / D I$ & $\Delta r / 1 Q$ & عادى & & \\
\hline & & & & & $r \mid / \cdot$ & $F V / l$. & ضداجتماعى & \multirow[t]{3}{*}{ ارزش هيجان } & \\
\hline & & & & & $r V / Q 9$ & $\mathrm{Fr} / \mathrm{Q}$. & وسواسى & & \\
\hline & & & & & $r F / I q$ & $F N / F F$ & عادى & & \\
\hline
\end{tabular}

شدت و ارزش هيجان خشم بالاترين ميانگين

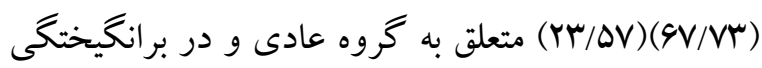
(FN/GF) متعلق به شخصيت وسواسى است. ادامه در جدول ا-ارائه شده است. در جدول r شاخصهاى توصيفى انواع بازشناسى هيجان تن در سه حالت يكيارجّه نورانى، قطعه نورانى، نقطه نورانى در سه گروه شخصيت ضداجتماعى و شخصيت وسواسى و عادى آورده شده
همان گونه كه نتايج جدول ا نشان مى دهد، بالاترين ميانگين در انواع بازشناسى هيجان در حالت صوت در سه

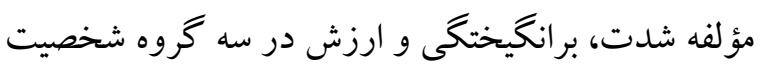
ضداجتماعى و شخصيت وسواسى و عادى به ترتيب در هيجان ترس و خنثى بالاترين ميانگين در مؤلفه شدت و و و برانگيختكى (

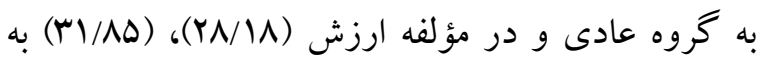
اختلال شخصيت ضداجتماعى تعلق دارد. در مؤلفهى

جدول r ميانكين و انحراف معيار بازشناسى هيجان تن در سه كروه

\begin{tabular}{|c|c|c|c|c|c|c|c|c|c|}
\hline انحراف & ميانكين & كروه & حالت & هيجان & انحراف & ميانكين & كروه & حالت & هيجان \\
\hline$r / r \Delta$ & $9 / N$ & ضداجتماعى & \multirow{3}{*}{ يكֶ) ֶه نورانى } & \multirow{9}{*}{ خنثى } & T/Y & $V / r$. & ضداجتماعى & \multirow{3}{*}{ يكֶֶ, جه نورانى } & \multirow[t]{9}{*}{ خشم } \\
\hline$r / 90$ & $\Delta / V \mu$ & وسواسى & & & $1 / 4 q$ & $V / r$. & وسواسى & & \\
\hline$r / 99$ & $9 / . r$ & عادى & & & $1 / \Delta F$ & V/Ir & عادى & & \\
\hline Y/VG & ه/AG & ضداجتماعى & \multirow{3}{*}{ قطعه نورانى } & & $1 / 09$ & V/Nr & ضداجتماعى & \multirow[t]{3}{*}{ قطعه نورانى } & \\
\hline$r / 9 F$ & $9 / 19$ & وسواسى & & & $1 / 9 V$ & $V / \& 4$ & وسواسى & & \\
\hline$r / .9$ & $9 / \Delta r$ & عادى & & & $1 / 11$ & $V / \Delta 1$ & عادى & & \\
\hline$r / v$. & $9 / . r$ & ضداجتماعى & \multirow{3}{*}{ نقطه نورانى } & & I/VQ & $V / \Delta$. & ضداجتماعى & \multirow[t]{3}{*}{ نقطه نورانى } & \\
\hline r/VF & $9 / . r$ & وسواسى & & & $r / \cdot$ & $9 / 94$ & وسواسى & & \\
\hline$r / F V$ & $9 / 09$ & عادى & & & $1 / \wedge \Delta$ & $\mathrm{V} / \mathrm{r}$. & عادى & & \\
\hline $1 / r \Delta$ & $\Lambda / \Delta \varphi$ & ضداجتماعى & \multirow{3}{*}{ يكِار جه نور انى } & \multirow[t]{6}{*}{ ترس } & $1 / Y q$ & $9 / \cdot r$ & ضداجتماعى & \multirow[t]{3}{*}{ يكِارجه نورانى } & \multirow[t]{6}{*}{ شادى } \\
\hline $1 / 01$ & $1 / 19$ & وسواسى & & & I/DF & $\Lambda / F r$ & وسواسى & & \\
\hline $1 / 94$ & $V / a$. & عادى & & & 1/or & $\wedge / 1$ & عادى & & \\
\hline $1 / .9$ & N/99 & ضداجتماعى & \multirow{3}{*}{ قطعه نورانى } & &.$/ 99$ & N/99 & ضداجتماعى & \multirow[t]{3}{*}{ قطعه نورانى } & \\
\hline I/FY & N/9. & وسواسى & & & $1 / 94$ & $1 / 94$ & وسواسى & & \\
\hline$r / f$. & V/Nr & عادى & & & IVY & V/Ar & عادى & & \\
\hline
\end{tabular}




\begin{tabular}{|c|c|c|c|c|c|c|c|c|}
\hline $1 / \mathrm{V} 1$ & N/I & ضداجتماعى & \multirow{3}{*}{ نقطه نورانى } & $\cdot / A \cdot \Lambda$ & $9 / 44$ & ضداجتماعى & \multirow[t]{3}{*}{ نقطه نورانى } & \\
\hline $1 / 91$ & N/YG & وسواسى & & $1 / Y Y$ & N/9 & وسواسى & & \\
\hline r/IV & $V / r r$ & عادى & & I/FY & $N / \cdot r$ & عادى & & \\
\hline$r / 10$ & $\Delta / \mu$. & ضداجتماعى & \multirow{3}{*}{ يكِار جهه نورانى } & $1 / 19$ & $V / \Delta G$ & ضداجتماعى & \multirow{3}{*}{ يكيارجه نورانى } & غم \\
\hline$r / 9 \mid$ & $\Delta / r$. & وسو اسى & & $1 / \Delta \wedge$ & V/r & وسواسى & & \\
\hline$r / \cdot$ & $\Delta / r$. & عادى & & $1 / 9$ & $9 / 1$. & عادى & & \\
\hline$r / T r$ & $9 / r \mu$ & ضداجتماعى & \multirow[t]{3}{*}{ قطعه نورانى } & $1 / 90$ & V/AG & ضداجتماعى & \multirow[t]{3}{*}{ قطعه نورانى } & \\
\hline$r / 9 V$ & $\Delta / Y q$ & وسواسى & & $1 / r^{4}$ & V/ar & وسواسى & & \\
\hline r/AY & G/rr & عادى & & $r / \cdot r q$ & V/rT & عادى & & \\
\hline r/MT & $\Delta / F$ & ضداجتماعى & \multirow[t]{3}{*}{ نقطه نورانى } & l/gF & $V / 19$ & ضداجتماعى & \multirow[t]{3}{*}{ نقطه نورانى } & \\
\hline$r / F$. & $\Delta / r$. & وسواسى & & $1 / 91$ & $V / 19$ & وسواسى & & \\
\hline Y/YF & 91.9 & عادى & & $r / .9$ & $9 / 4$. & عادى & & \\
\hline
\end{tabular}

جدول r ارائه شده است. در جدول r شاخصهاى توصيفى انواع بازشناسى هيجانهاى جهره، در سه گروه شخصيت ضداجتماعى و شخصيت وسواسى و عادى

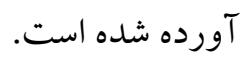

همان گونه كه نتايج جدول ب نشان مى دهد در هيجان خشم در هر سه حالت يكيارجه نورانى (·r/T)، قطعه نورانى (V/VT) نقطه نورانى (V/O/)، بالاترين ميانگين متعلق به كروه شخصيت ضداجتماعى است. ادامه در

جدول r ميانكين و انحر اف معيار بازشناسى هيجان صوت، تن و جهره در سه كروه

\begin{tabular}{|c|c|c|c|}
\hline انحراف استاندارد & ميانكين & Fروه & متغير \\
\hline $1 / 10$ & $F / \mu^{4}$ & شخصيت ضداجتماعى & \multirow[t]{3}{*}{ هيجان خشم } \\
\hline $1 / 4 \lambda$ & $F /$ Yq & اختلال شخصيت وسواسى & \\
\hline $1 / 11$ & F/Ar & عادى & \\
\hline $1 / r$ & $\mu / \mu$. & اختلال شخصيت ضداجتماعى & \multirow[t]{3}{*}{ هيجان ترس } \\
\hline $1 / F V$ & $r / \uparrow$. & اختلال شخصيت وسواسى & \\
\hline $1 / r y$ & 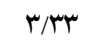 & 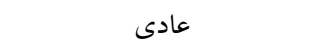 & \\
\hline$\cdot / 4 \cdot 9$ & $\Delta / \wedge$ & اختلال شخصيت ضداجتماعى & \multirow[t]{3}{*}{ هيجان غم } \\
\hline$\cdot 19 \mathrm{~V}$ & $\Delta / 4$ & اختلال شخصيت وسواسى & \\
\hline$\cdot / \Delta F$ & $0 / 99$ & عادى & \\
\hline$\cdot / \wedge \Delta$ & $\Delta / \mathcal{F}$ & اختلال شخصيت ضداجتماعى & \multirow[t]{3}{*}{ هيجان تنفر } \\
\hline$\cdot / 91$ & $\Delta / Y q$ & اختلال شخصيت وسواسى & \\
\hline$\cdot 191$ & $\Delta / 9 \mu$ & 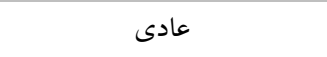 & \\
\hline$\cdot / \Lambda$ & $\Delta / 94$ & اختلال شخصيت ضداجتماعى & \multirow[t]{3}{*}{ هيجان شادى } \\
\hline 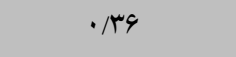 & $\Delta / 9$ & اختلال شخصيت وسواسى & \\
\hline$\cdot / r \Delta$ & $\Delta / 9$ & عادى & \\
\hline 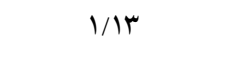 & $\Delta / 4$ & اختلال شخصيت ضداجتماعى & \multirow[t]{2}{*}{ هيجان تعجب } \\
\hline$\cdot / \Delta r F$ & $\Delta / v$ & اختلال شخصيت وسواسى & \\
\hline
\end{tabular}




\begin{tabular}{|c|c|c|c|}
\hline$\cdot / r V$ & D/A & عادى & \\
\hline$\cdot / \wedge \Delta$ & $\Delta / \mu^{-1}$ & اختلال شخصيت ضداجتماعى & \multirow[t]{3}{*}{ 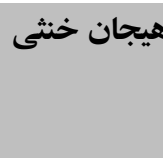 } \\
\hline$I / F V$ & $\Delta / 1 \Gamma$ & اختلال شخصيت وسواسى & \\
\hline - $/ M M q$ & $\Delta / \cdot r$ & عادى & \\
\hline
\end{tabular}

لوين) و همكنى ماتريس كوواريانسها (ام باكس)

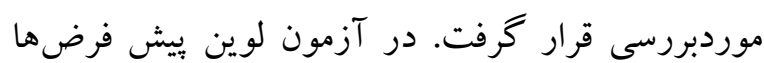
تائيد شد. در بيشفرض آمارهى ام. باكس متغير بازشناسى

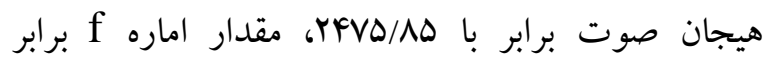

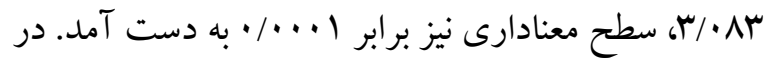
بيشفرض آمارهى ام. باكس بازشناسى هيجان تن برابر با با برابر f f برابر NFF/GFV

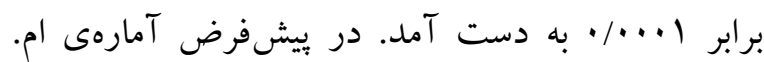
باكس بازشناسى هيجان جهره برابر با بV/YVD، مقدار

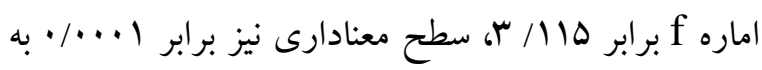

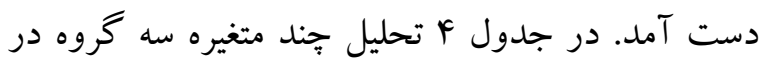

بازشناسى هيجان صوت، تن و جهره ارائه شده است.
همان گونه كه در جدول ب نشان مى دهد در مؤلفهى بازشناسى هيجان جهره خشم بالاترين ميانگين (F/AK) مربوط به گروه عادى است. در مؤلفه بازشناسى هيجان

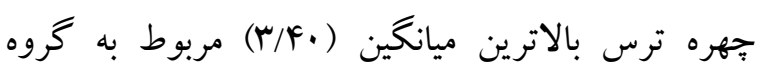
شخصيت وسواسى است. در مؤلفهى بازشناسى هيجان

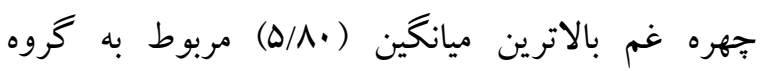
شخصيت ضداجتماعى بود. ادامه در جدول ب ارائه شده است. در شاخص توصيفى نظريه ذهن در سه گروه شخصيت ضداجتماعى و شخصيت وسواسى و عادى

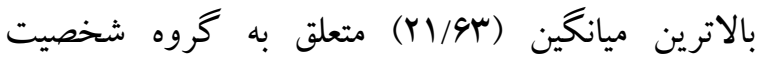
ضداجتماعى بود.

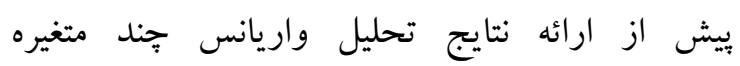
ييش فرضهاى مربوطه، شامل همخنى واريانسها (آزمون لمين

جدول F تحليل جند متغيره سه تروه در بازشناسى هيجان صوت، تن و جهره

\begin{tabular}{|c|c|c|c|c|c|}
\hline توان آمارى & سطح معنادارى & آماره f & مقدار & اثر & بازشناسى هيجان \\
\hline$\cdot / 99 \mathrm{~V}$ &.$/ \cdot$ If & $1 / 9 V D$ & •/VMA & اثر بيلايى & \\
\hline
\end{tabular}

براساس نتايج آزمون تحليل جند متغيره كه در جدول

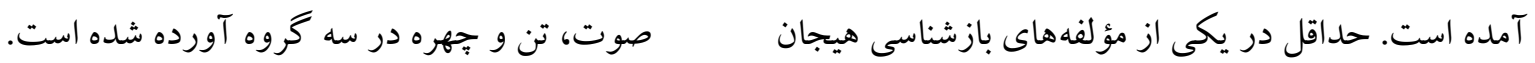
بين گروههاى يُزوهش تفاوت معنادار وجود دارد. در برد

جدول ه تحليل واريانس كك متغيره بازشناسى هيجان صوت، تن و جهره در سه كروه

\begin{tabular}{|c|c|c|c|c|c|c|}
\hline تمارى & معنادارى سطح & آماره f & مجذانكين & آزادى درجه & مجذوروات & متغير وابسته \\
\hline \multirow[t]{2}{*}{. DYG } & $\cdot / \cdot v 1$ & Y/VYA & $\Lambda G K / I V F$ & r & IVTG/KFS & شدت خشم \\
\hline & & & MIG/FYr & $\Lambda \mu$ & TEYGT/..I & \\
\hline$\cdot / \cdot V F$ & ./ADr & $\cdot 1109$ & MF/AYA & r & $99 / 909$ & ارزش خشم \\
\hline
\end{tabular}




\begin{tabular}{|c|c|c|c|c|c|c|}
\hline & & & r19/IFG & $\Lambda r$ & $|\wedge| \wedge q / 1 \mu \Delta$ & \\
\hline \multirow[t]{2}{*}{.1909} & $\cdot / \cdot r \cdot *$ & $r / 9 \Delta \Lambda$ & IAAV/Arq & r & & برانتيختغى خشم \\
\hline & & & $\Delta 19 / 1 \% \Lambda$ & $\Lambda r$ & FrAKq/FIG & \\
\hline \multirow[t]{2}{*}{$\cdot / 419$} & 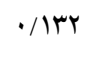 & $r / \cdot V q$ & $9 \cdot N / 9 \Delta \mathrm{F}$ & r & $|r| V / a \cdot V$ & شدت شادى \\
\hline & & & $r Q r / r y$. & $\Lambda$ & TFMEV/TMD & \\
\hline \multirow[t]{2}{*}{ • } & $\cdot / r \Delta l$ & $1 / \cdot \Delta q$ & $r \cdot 1 / 9 \wedge \Delta$ & r & $F \cdot r / q V I$ & ارزش شادى \\
\hline & & & $19 \cdot 19 \Delta r$ & $\Lambda r$ & IDAYF/YYG & \\
\hline \multirow[t]{2}{*}{$\cdot / \cdot 9 V$} & $\cdot / V r q$ & $\cdot / r \cdot F$ & Ird/AKr & r & & برانَيختكى شادى \\
\hline & & & $f \mid r / \wedge 90$ & $\Lambda r$ & rFro./VGD & \\
\hline \multirow[t]{2}{*}{$\cdot / \cdot V F$} & - /ADr &.$/ 19$ & $F \cdot / 0 \cdot 1$ & r & $\wedge 1 / \cdot r$ & شدت ترس \\
\hline & & & $r \Delta Y / F q \Delta$ & $\Lambda \mu$ & $r \cdot 9 \Delta V / \cdot \wedge \Delta$ & \\
\hline \multirow[t]{2}{*}{$\cdot / \Delta \cdot \Delta$} & $\cdot / \cdot \wedge$ & $r / 9 .$. & $\Delta Y \wedge / Q Y \Lambda$ & r & $1 \cdot \Delta V / A V V$ & ارزش ترس \\
\hline & & & $r \cdot r / F r l$ & $\Lambda r$ & $19 \Lambda M F / V F G$ & \\
\hline \multirow[t]{2}{*}{.$/ .01$} &.$/ 99$. & $\cdot / \cdot 1$ & $f / l \cdot f$ & r & & 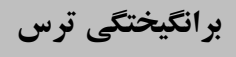 \\
\hline & & & FrV/.Fr & $\lambda r$ & RDFFF/DFY & \\
\hline \multirow[t]{2}{*}{$\cdot / r \cdot \Delta$} & $\cdot / 4 \cdot 1$ & $\cdot / 9 r \Delta$ & YAY/YYV & r & $\Delta G F / F \Delta F$ & شدت درد \\
\hline & & & $r \cdot \Delta / \cdot G F$ & $\Lambda$ & YOHY./YAQ & \\
\hline \multirow[t]{2}{*}{.$/ 199$} & $\cdot / 499$ & $\cdot / V \cdot 9$ & $|\Delta \Delta / Y| Y$ & r & MI./Fro & ارزش درد \\
\hline & & & rIQ/VDA & $\lambda r$ & IArrq/qur & \\
\hline \multirow[t]{2}{*}{$\cdot / 1 \wedge 1$} & $\cdot / F \Delta G$ & - var & YNI/GTD & r & $\Delta G T / Y F q$ & بر انكيختكى درد \\
\hline & & & rob/VMr & $\Lambda$ & rQDYQ/A9V & \\
\hline \multirow[t]{2}{*}{$\cdot / \mu 10$} & . TrS & l/Dr. & $9.9 / r \Delta q$ & $r$ & $|r| r /|V|$ & شدت ت شنفر \\
\hline & & & $r q q / \cdot \cdot v$ & $\Lambda \mu$ & $M T I V / \Delta 99$ & \\
\hline \multirow[t]{2}{*}{ • } & $\cdot / 4 \Delta 1$ & $1 / .91$ & $110 / \Delta 99$ & r & rVI/Iro & ارزش تنفر \\
\hline & & & $\mid V F / \Lambda 9 \Lambda$ & $\lambda r$ & $|F \Delta| F / .99$ & \\
\hline \multirow[t]{2}{*}{$.1 .9 F$} & - VOr & / TAS & & r & YrF/DY. & بر انكيخ \\
\hline & & & $\mid F l \cdot / r \Delta \Delta$ & $\Lambda \mu$ & $M F \cdot \Delta q / F \Delta \Lambda$ & \\
\hline \multirow[t]{2}{*}{ • I Trg } & 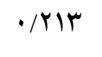 & $1 / \Delta V$ & rAG/IrV & r & $V V Y / T V Y$ & شدت غم \\
\hline & & & YFF/AVI & $\Lambda$ & Y.MYF/MIF & \\
\hline \multirow[t]{2}{*}{.$/ \mathrm{Fr}$} & $\cdot 1099$ & $\cdot / \Delta V F$ & $1 \pi / 1 \cdot 9$ & r & $r q V / 911$ & ارزش غم \\
\hline & & & $r M r / Y \cdot F$ & $\Lambda$ & $19 r \Delta \Delta / q F q$ & \\
\hline \multirow[t]{2}{*}{$\cdot / T \Delta F$} & $\cdot / \mu$ & $1 / M M$ & $\Delta r Y / \Lambda \cdot q$ & r & $1.90 / 91 \mathrm{~V}$ & برانكيختكى غم \\
\hline & & & FFN/FGY & N & MVYYY/rq. & \\
\hline \multirow[t]{2}{*}{$\cdot / 1 \cdot 4$} & $\cdot / v \cdot \wedge$ & - MFG & YFD/FTD & $r$ & $\Lambda v \cdot / \& q$. & شدت تعجب \\
\hline & & & $V \cdot N / 9 F V$ & $\lambda$ & $\Delta M \Lambda I V / 9 \Lambda I$ & \\
\hline \multirow[t]{2}{*}{. TYY } & $\cdot / r 9 \Delta$ & I/TMV & $99 . / Y \Delta 9$ & r & $1 T r \cdot / 01 Y$ & ارزش تعجب \\
\hline & & & $\Delta M T / \Delta Q q$ & 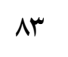 & FFYMA/VOF & \\
\hline$\cdot / \cdot \vee \wedge$ & ./Arq & $\cdot / M M$ & $1 \cdot 0 / \cdot 91$ & r & $r 1 \cdot / 1 \Delta q$ & برانتيختكى تعجب \\
\hline
\end{tabular}




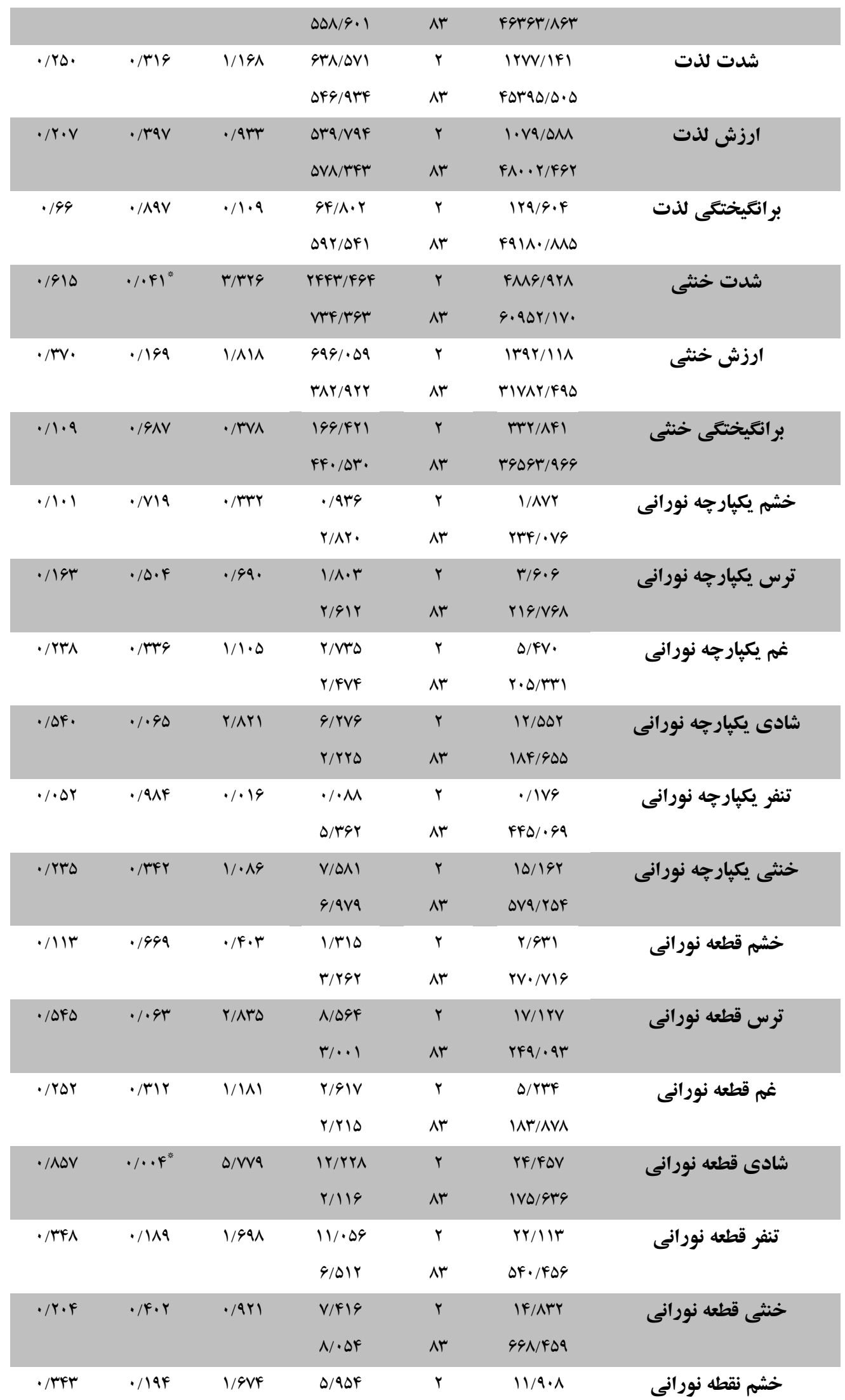




\begin{tabular}{|c|c|c|c|c|c|c|}
\hline & & & $r / \Delta \Delta Q$ & N & $r Q \Delta / 1 M$ & \\
\hline \multirow[t]{2}{*}{$\cdot / 490$} & . /rar & I/TFA & F/rOY & r & $N / \Delta \cdot r$ & ترس نقطه نورانى \\
\hline & & & $r / 4.9$ & $\Lambda r$ & YAY/9GF & \\
\hline \multirow[t]{2}{*}{ ( ) } & $\cdot / r \cdot \Delta$ & $1 / 919$ & $\Delta / F \vee q$ & $r$ & $1 \cdot / 9 \Delta \wedge$ & غم نقطه نورانى \\
\hline & & & $r / r q$. & $\Lambda r$ & $r \wedge I / r \Delta F$ & \\
\hline \multirow[t]{2}{*}{$\cdot / 919$} & $\cdot 1 \cdot \cdot 1^{*}$ & $1 \cdot / 9 \cdot 1$ & $|f / \Delta|$ & r & $r q / \cdot r \cdot$ & شادى نقطه نورانى \\
\hline & & & 1/r. & $\Lambda r$ & $11 \cdot / k \cdot r$ & \\
\hline \multirow[t]{2}{*}{$\cdot / \mu \cdot 9$} & 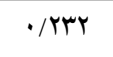 & $1 / 4 \wedge 9$ & $\mathrm{~V} / \wedge 9 \Delta$ & r & 10/Va. & نقطه نورانى \\
\hline & & & $\Delta / r \cdot r$ & $\Lambda r$ & $F F \cdot / \cdot \mu_{1}$ & \\
\hline \multirow[t]{2}{*}{$\cdot / \Lambda \Lambda Y$} & - far & ./V99 & $\Delta / v \cdot V$ & r & & ع نقطه نورانى \\
\hline & & & V/Irq & $\Lambda r$ & $\Delta Q Y / \Delta \cdot V$ & \\
\hline \multirow[t]{2}{*}{ •/rq. } & $\cdot /$ lor & $1 / 949$ & r/AIr & r & D/9YG & هيجان جهره خشم \\
\hline & & & $1 / 4 \Delta Q$ & $\Lambda$ & $|r| / .91$ & \\
\hline \multirow[t]{2}{*}{$\cdot / \cdot \Delta F$} & $\cdot / \vee १ \wedge$ & $\cdot / r Y V$ & & r & $\cdot / 1 \cdot 9$ & ، هيجان جهره ترس \\
\hline & & & I/VAD & $\Lambda r$ & IFN/ITT & \\
\hline \multirow[t]{2}{*}{$\cdot / \mathrm{IVA}$} & . / Far & •/VVG & •/YM & r & $\cdot /$ FV & بازشناسى هيجان جهره غم \\
\hline & & & $\cdot / \mu \cdot v$ & $\wedge r$ & $r \Delta / \& q 1$ & \\
\hline \multirow[t]{2}{*}{ 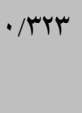 } & $\cdot / Y 19$ & $1 / \Delta 94$ & $1 / 1.9$ & r & $r / Y \backslash \Lambda$ & بازشناسى هيجان هجره تنفر \\
\hline & & & $\cdot / v \cdot 9$ & $\Lambda r$ & $\Delta \wedge / 199$ & \\
\hline \multirow[t]{2}{*}{.$/ 111$} & .190 & $\cdot /$ frF & $\cdot / \cdot r$ & r & .1 .94 & بازشناسى هيجان جهره شادى \\
\hline & & & $\cdot / \cdot \mathrm{Vr}$ & $\Lambda r$ & $4 / \cdots v$ & \\
\hline \multirow[t]{2}{*}{.1199} & - /faf & $\cdot / \mathrm{V} 11$ & $\cdot \mid F Y$ & r & - /AFr & بازشناسى هيجان جهره \\
\hline & & & - /09r & $\wedge r$ & $9 q / 191$ & تعجب \\
\hline \multirow[t]{2}{*}{.$/ 10$} & / /DFT & $\cdot 1910$ & $\cdot / V 9 \Delta$ & r & l/or. & بازشناسى هيجان جهره خنثى \\
\hline & & & I/TFF & $\Lambda r$ & I. T/YYA & \\
\hline
\end{tabular}

مؤلفهاى تو انايى بازشناسى هيجان تن فقط مؤلفهاى

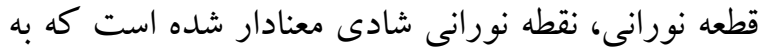

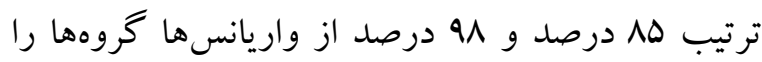
تبيين مى كند. در جدول 9 نتايج مقايسه زوجى سه كروه در بازشناسى هيجان صوت و تن ارائه شده است.
جنانجه در جدول هـ مشاهده مىشود با اجراى تحليل واريانس تكك متغيره از بين مؤلفهاى توانايى بازشناسى هيجان صوت فقط مؤلفههاى برانكيختكى خشم و شدت خنثى معنادار شده است كه به ترتيب 90 درصد و 91 درصد از واريانسها كروهها را تبيين مى كنند. از بين

جدول 7 نتايج مقايسه زوجى سه كروه در بازشناسى هيجان صوت و تن

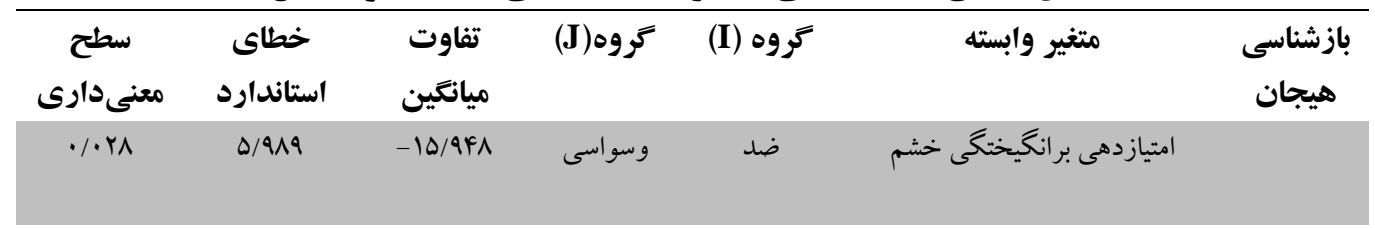




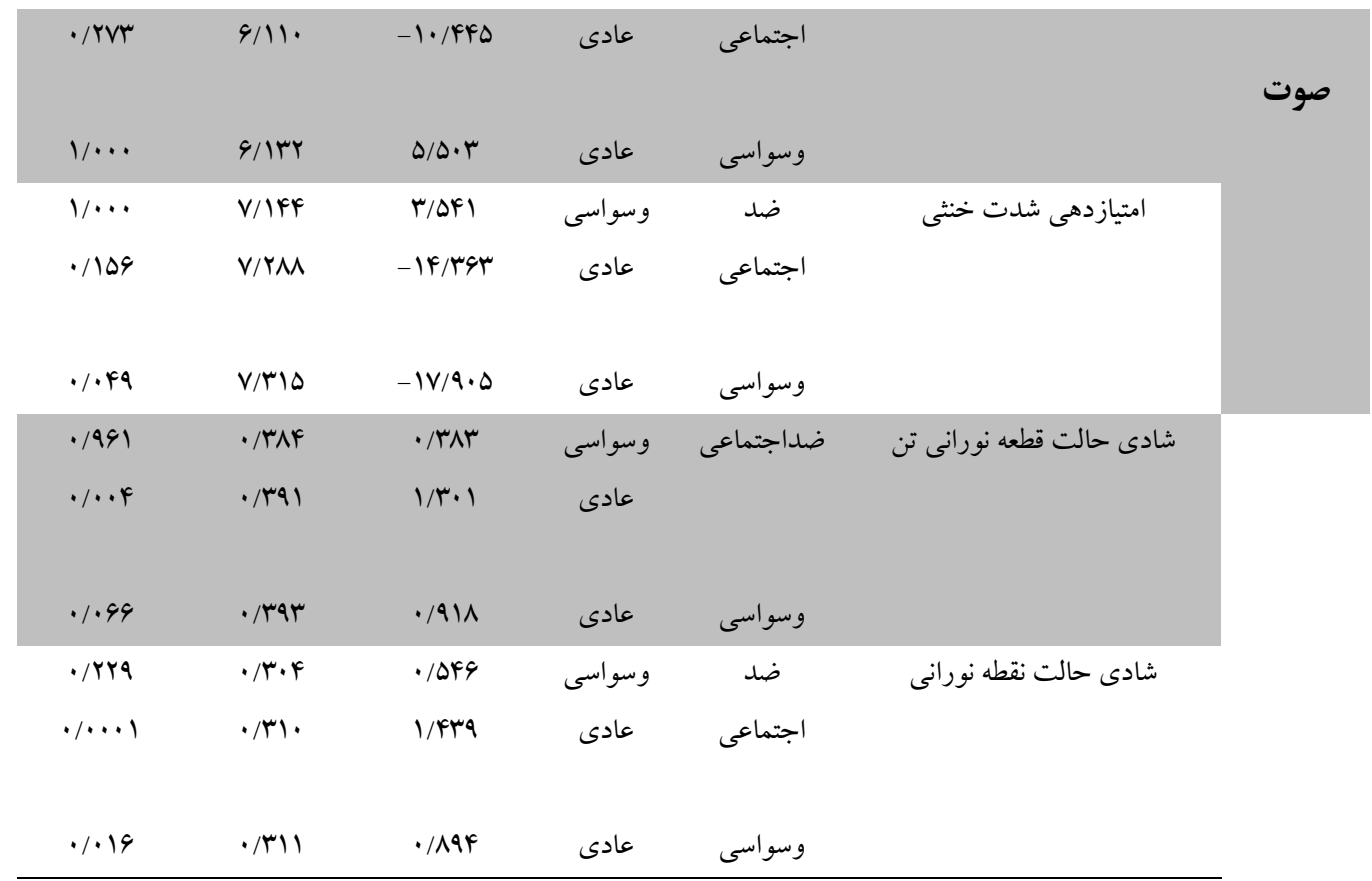

وسواسى و عادى بود. در اين يثزوهش تفاوتى در صحت بازشناسى هيجان صوت مشاهده نشد؛ اما كروه شخصيت ضداجتماعى و وخصيت وسواسى در امتيازدهى' برانگيختكى هيجان خشم باهم متفاوت بودند به طورى كه كروه شخصيت ضداجتماعى در امتيازدهى برانگيختخى هيجان خشم امتياز كمترى نسبت به گروه شخصيت وسواسى به اين مؤلفه دادند. بروكك وكوسن

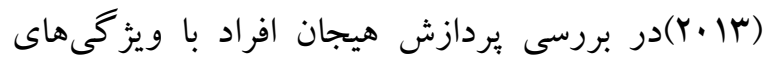
جامعهتيز، ناهنجارىهايى در تفسير رفتارى، روانى - روكئ فيزيولوزيكى و فعاليت مناطق مغزى در هنگام يردازش هيجانها مشاهده كردند؛ اما جامعهستيزها در مقايسه با كروه كنترل در امتيازدهى برانخيختخى خود، شدت و ارزش محرك ارائهشه تفاوتى نداشت. در تبين به تفاوت بازشناسى هيجان صوتى (تنها در خشم) در اختلال شخصيت ضداجتماعى مىتوان كفت؛ بر اساس راهنماى

- Rating

2- Brook \& Kosson
همانطور كه جدول 9 نشان مىدهد در امتياز دهى برانكيختكى خشم در دو كروه شخصيت ضداجتماعى و شخصيت وسواسى (pN (p) ) و در امتيازدهى شدت خنتى، دو گروه شخصيت وسواسى و عادى تفاوت معنادار (pq (p=است. در بازشناسى هيجان شادى دو

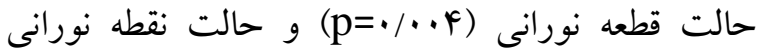

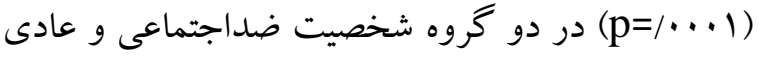
تفاوت معنادار است. همجنين در هيجان شادى گروه شخصيت وسواسى و كروه عادى در حالت نقطه نورانى

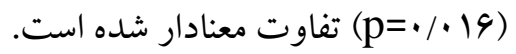

هدف يثزوهش حاضر مقايسه ابعاد بازشناسى هيجان و نظريه هن در نمونهاى غير بالينى شخصيت ضداجتماعى، شخصيت وسواسى و عادى بود. نتايج يزوهش حاكى از وجود تفاوت در بازشناسى هيجان در روشهاى مختلف در شخصيت ضداجتماعى، شخصيت 
فرايزن (9V9) (1) شادى؛ بهعنوان بارزترين هيجان در

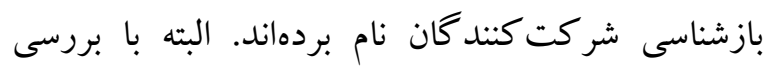

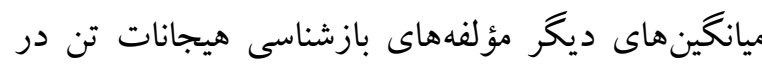

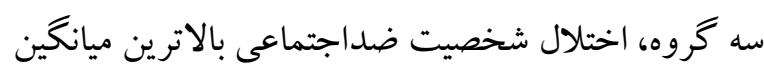
در صحت بازشناسى هيجانات خشم ،شادى (سه حالت) ، ترس، تنفر، غم (دو حالت) و خنثى (يكك حالت) را نسبت به دو گروه داشت. به نظر مىرسد اين تفاوت مربوط به مركز ثقل محرككهاى اجتماعى است بهعنوانمثال افراد عادى و شخصيت وسواسى بهمنظور بازشناسى هيجانات به جهره بهعنوان يكك منبع اصلى متمركز مىشوند؛ اما افراد ضداجتماعى؛ ازآنجاكه در تعاملات خود در دو مقوله تدافعى و تهاجمى عكسالعمل نشان مىدهند بررسى وضعيت تنى يا حر كات بلدن افراد براى آنها يكك نشانه مهم است؛ بنابراين طبيعى به نظر مىرسد كه در نظر

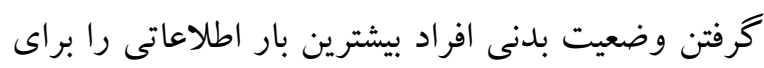
اين اختلال داشته باشد؛ در يكك جمعبندى كلى در مورد افراد مبتلابه شخصيت ضداجتماعى و جامعهتيزها

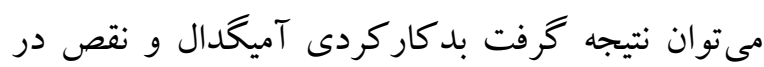
بازشناسى هيجانهاى ترس و غم بيشترين موارد تائيد و اكثر تحقيقات از روش ابراز جهره و سيس از روش صوت براى بازشناسى هيجان استفاده كردهاند و از روش تن كمتر استفادهده است؛ بنابراين در مورد بازشناسى هيجان از روش حر كات بدن به تحقيقات بيشترى در اين افراد نياز است. عليرغم شيوع بالاى اختلال شخصيت وسواسى، توجه بروهشى كافى به آن نشده است (بلشفيلد

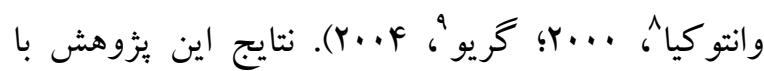
نتايج داروس، زاكزانيس و و و ركتور (Y.|F)،

7. Ekman \& Friesen

8- Blashfield \& Intoccia

${ }^{9}$ - Grilo
آمارى و تشخيصى بيمارىهاى روانى اين افراد داراى ويز كى هايى شامل بى توجهى بى باكانه نسبت به امنيت خود و ديخران و صفت شخصيتى جسور بودن و فقدان ترس هستند؛ بنابراين صداى خشم تأثير كمترى بر آنها

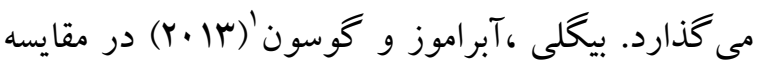
زندانيان جامعهستيز و زندانيان عادى در بازشناسى هيجان

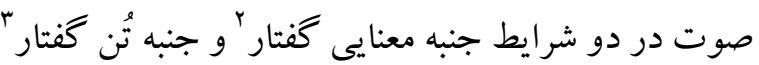
به اين نتايج رسيدند كه جامعهستيزها نقص كلى در دستهبندى نشانههاى معنايى گفتار و نقص خاص در دو دو هيجان غم و شادى دارند. در بازشناسى هيجان حركات بدن گروه شخصيت ضداجتماعى و عادى در دو حالت قطعه نورانى و نقطه نورانى هيجان شادى متفاوت بودند؛ به صورتى كه شخصيت ضداجتماعى عملكرد بهترى نسبت به گروه عادى داشت. در فرا تحليلى توسط داول،

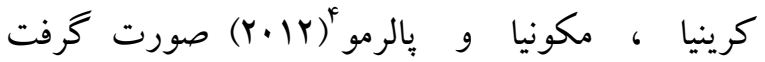
شواهدى از بازشناسى هيجان جهره، صوت و وضعيتى هدر جامعهستيزها باهدف روشن كردن اينكه آيا نقص در بازشناسى هيجانات منحصر به هيجان خاصى است يا فراكير هستند؟ انجام شد. اين فرا تحليل شواهدى از اختلالات آشكارى در سراسر روشها براى هند هيجان (نهفقط، ترس و غم) در بزرگكالان و نوجوانان مشاهده

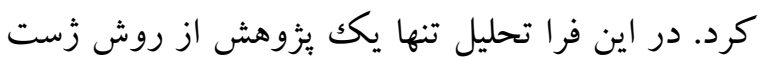
بدن در بازشناسى هيجان ترس صورت كرفته بود(مونوز

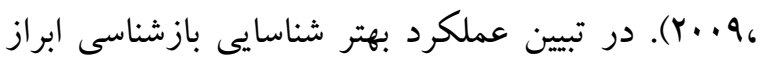
هيجان تنى(تنها در شادى )در اختلال شخصيت

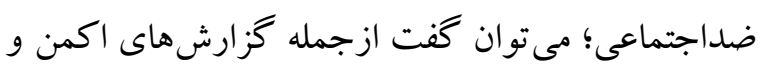

\footnotetext{
1- Bagley, Abramowitz\& Kosson

2- Semantic speech

3. Prosodic speech

4- Dawel, O’kearney, McKone \& Palermo

5 - Postural

6. Muñoz
} 
نشد. خرازى ، مدرس غروى، بهشتى زاده و هاشميان (YMM()در تحقيقى متشكل از نمونهاى مبتلايان به اختلال وسواسى- جبرى ،تفاوت مهمى در بازشناسى حالات هيجانى جهره بين افراد مبتلابه اختلال وسواس جبرى و همتايان بهنجار آنها مشاهده نكردند. در نظريه ذهن تفاوتى بين سه گروه شخصيت ضداجتماعى و و شخصيت وسواسى و عادى مشاهده نشد. نتايج يزوهش

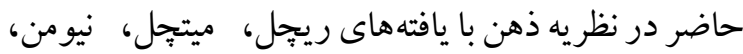

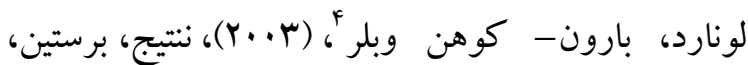
بر كلن واسلاته (ه) (Y) همسو با يافته هاى برو كتور و

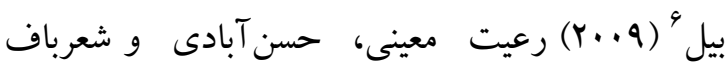
(سوبا) نا همسو است. در تحقيقى كه توسط ننتج،

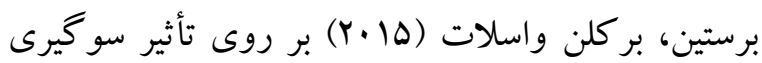
خصومت با كنترل سرعت يردازش خودكار (آهسته و سريع) در آزمون نظريه ذهن جشمها در سه كروه جامعهستيز مجرم، جامعهستيز غير مجرم و عادى صورت كرفت به اين نتيجه رسيدند كه افراد جامعهتيز، اكر محدوديت زمانى براى يردازش ذهن خوانى جشم نداشته باشند عملكردشان با ديخر گرووها تفاوتى نخو اهد داشت. رعيت معينى، حسن آبادى و شعرباف (سهبا) در بررسى نظريه ذهن و كنشهاى اجرايى در بيماران مبتلابه اختلالهاى وسواسى -جبرى، دوقطبى، اسكيزوفرنى و افراد بهنجار به اين نتيجه رسيدند كه بيماران وسواسى جبرى، اسكيزوفرنى و دوقطبى نسبت به گروه بهنجار در توانايىهاى نظريه ذهن و كنشهاى اجرايى عملكرد

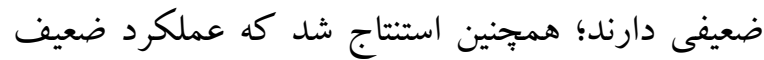
در تكليف نظريه ذهن و كنشهاى اجرايى به وجود
كونرايك، بلارى، فيلويوب، دانا، فويسيا، هسك،

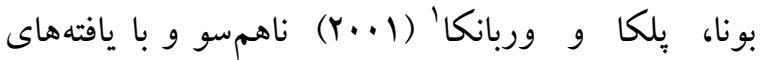
خرازى، مدرس غرورى، بهشتى زاده و هاشميان(ا(9))،

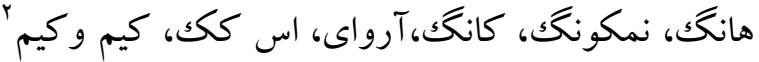

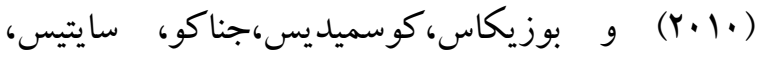

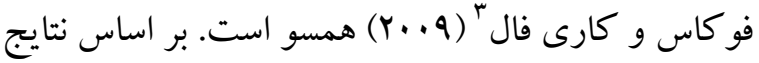
نتايج مطالعه حاضر دو گروه شخصيت وسواسى و عادى در صحت بازشناسى هيجان صوت تفاوتى نداشتند؛ اما در امتيازدهى شدت خنثى، متفاوت بودند؛ به طورى كه افراد شخصيت وسواسى نمره شدت خنثى كمترى نسبت به كروه عادى به اين مؤلفه دادند.در تحقيقى توسط بوزيكاس وهمكاران (q..... در افراد اختلال وسواس جبرى در صحت بازشناسى هيجان به روش جهره و صدا با كروه سالم تفاوتى مشاهده نكرد. در تبيين امتيازدهى كمتر شدت خنثى در شخصيت وسواسى نسبت به گروه عادى، بر اساس ملاككهاى راهنماى آمارى و تشخيصى بيمارىهاى روانى به خاطر ويز گیىهاى شخصيتى هيجان بذيرى محدود و در جاماندگى كه احتمالاً به دليل ترديدشان در بازشناسى هيجانها است خطر كمترى را مىيذيرند و در جاماندگى بيشترى دارند، درحالى كه كروه عادى بهرغم ترديدشان به بازشناسى هيجان مبادرت مىورزند. در مطالعه حاضر گروه شخصيت وسواسى بردي عملكرد بهترى در حالت نقطه نورانى هيجان شادى تن نسبت به گُروه عادى داشتند به نظرمى رسد افراد مبتلابه اختلال شخصيت وسواسى به علت اشتغال خاطر به جزئيات ، بهتر از گروه عادى بازشناسى كردهاند. در بازشناسى هيجان جهرهاى تفاوتى بين گرووها مشاهده

4- Richell, Mitchell, Newman, Leonard, Baron-Cohen \& Blair

5 - Nentjes, Arntz, Breukelen, Slaats

1- Kornreich, Blairy, Philippot, Dan, Foisy, Hess, Verbanck

${ }^{2}$ - Jhung, Namkoong, Kang, Ha, R. Y., An, S. K., Kim \& Kim,

6 - Proctor \& Beail

3 - Bozikas, Kosmidis, Giannakou, Saitis, Fokas \& Garyfallos 
تفاوتهاى فرهنكى، احتمالاً بيشترين مشكل را در رمز گشايى هيجانها، در افراد متعلق به گروههاى فرهنكى متفاوت، نسبت به فرستنده ايجاد مى كند. در يك فرا تحليل، الفنبين و آمبادى ' (r...r؛ به نقل از كوداكك، بلين، هاما، ماسودا، ماتسورا و اوكوبو، با·ץ) نتيجه

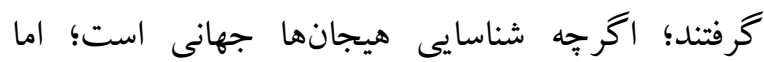
شواهدى از برترى بازشناسى هيجان، در داخل گرووه

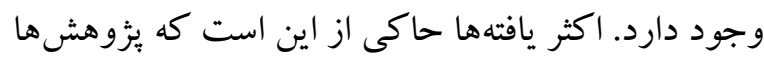
محدود به ابراز هيجان جهرهاى و غلبه طولانى نظريه هيجانهاى بنيادى است. تحقيقات آينده، بايد هيجانات را از ساير روشها و بهصورت طبيعىتر بررسى كنند. تا از

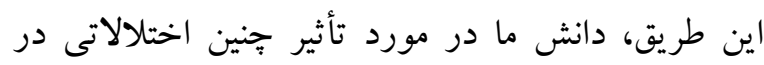

$$
\text { رفتار اجتماعى واقعى افزايش يابد. }
$$

\section{سياسگز ارى}

در يايان از تمامى كسانى كه ما را در اجراى هر جه بهتر اين بزظوهش بخصوص دانشجويان دانشگاه فردوسى مشهد همراهى كردهاند كمال تشكر و قدردانى مى كنيم.

\section{References}

Aigner M, Sachs G, Bruckmüller E, Winklbaur B, Zitterl W, Kryspin-Exner I, Katschnig H. (2007). Cognitive and emotion recognition deficits in obsessive-compulsive disorder. Psychiatry Research, 149(1-3), 121-128.

Albert U M G, Forner F, Bogetto F. (2004). DSMIV obsessive-compulsive personality disorder: prevalence in patients with anxiety disorders and in healthy comparison subjects. Comprehensive Psychiatry, (45), 325-332.

Amiri A, Ghasempour A, Fahimi S, Abolghasemi A, Akbari E, Agh A, Fakhari A. (2012). Recognition of Facial Expression of Emotion
شدت نقايص در توانايىهاى شناختى اين بيماران مرتبط

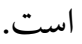

\section{نتيجه كيرى}

يافتهاى حاصل از جمعيت بالينى بهطور كلى نوعى نقص در بازشناسى هيجان را بيان مى كند. بالين حال، شواهد از

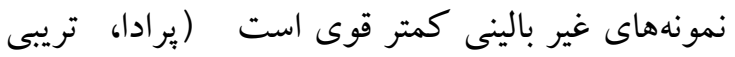
وكرو'، هاب(Y). لازم به ذكر است كه نمونهاى اين يُزوهش غير بالينى است درحالى كه در يُزوهشهاى قبلى

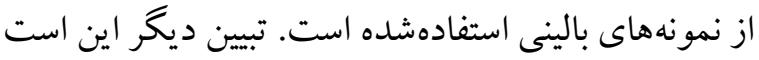

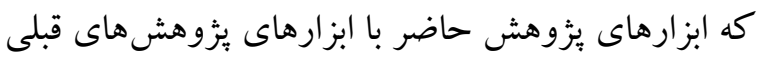

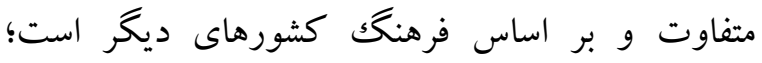
يثزوهشى براى بيان تفاوت بين فرهنكى در بازشناسى

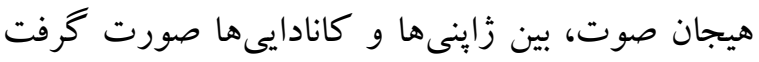
اين دو گروه در امتيازدهى شدت و ارزش، در هيجانات غم و شادى تفاوتى نداشتند؛ اما درشدت يايين و ارزش منفى، هيجانات خشم، تنفر و ترس بين اين دو گروه تفاوت معنادار بود. همجِنين در صداى هيجان لذت، ارزش مثبت، كمتر و شدت هيجان لذت هم كمتر، توسط شنوندكان زاينى امتيازدهى شد. نتايج نشان از اهميت تفاوت بين فرهنكى در درك ابراز هيجانات بايه مثبت و منفى كه بهصورت صداى غير كلامى است (كوداك، ليك بلين، هاما، ماسودا، ماتسورا و اوكوبو، با.·Y). تبيين ديخر از تفاوت بين فرهنگى، تفاوت در قانونهاى ابراز هيجانها در فرهنگكهاى مختلف است (كوداكى، بلين، هاما، ماسودا، ماتسورا و اوكوبو، با.·Y) بعلاوه كلمههاى استفادهشه، براى شرح يا تعريف كردن هيجانها، معنايشان بين زبانها متفاوت است؛ بديهى ست اين جنين لرهن

\footnotetext{
1. Prado, Treeby \& Crowe
} 
in Patients with Obsessive-Compulsive Disorder and Average People. Armaghane danesh, 17(1), 30-39. (In Persian)

American Psychiatric Association, Diagnostic and statistical manual of mental disorders(Fifth edition) DSM-5.(2013). Washington, DC: Author

Atkinson AP, Dittrich WH, Gemmell AJ, Young AW. (2004). Emotion perception from dynamic and static body expressions in point-light and full-light displays. Perception, 33(6), 717-746.

Bagley AD, Abramowitz CS, Kosson DS. (2009). Vocal affect recognition and psychopathy: Converging findings across traditional and cluster analytic approaches to assessing the construct. Joumal of Abnormal Psychology, 118(2), 388 .

Belin P, Fillion-Bilodeau S, Gosselin F. (2008). The Montreal Affective Voices: a validated set of nonverbal affect bursts for research on auditory affective processing. Behavior Research Methods, 40(2), 531-539.

Blashfield RK, Intoccia V. (2000). Growth of the literature on the topic of personality disorders. American Joumal of Psychiatry, 157(3), 472473.

Bozikas VP, Kosmidis MH, Giannakou M, Saitis M, Fokas K, Garyfallos G. (2009). Emotion perception in obsessive-compulsive disorder. Journal of the Intemational Neuropsychological society, 15(1), 148-153.

Brook M, Kosson DS. (2013). Impaired cognitive empathy in criminal psychopathy: Evidence from a laboratory measure of empathic accuracy. Joumal of Abnormal Psychology, $156(1) 122$.

Daros AR, Zakzanis KK, Rector NA. (2014). A quantitative analysis of facial emotion recognition in obsessive-compulsive disorder. Psychiatry Research, 215(3), 514-521.

Darvishi N, Alilou MM, Bakhshipour A, Farnam A, Bahramkhani M. (2013). Theory of mind in obsessive-compulsive disorder patients versus normal individuals. Adv Cogn Sci, (15), 78 . (In Persian)

Dawel A, O'keamey R, McKone E, Palermo R.
(2012). Not just fear and sadness: Metaanalytic evidence of pervasive emotion recognition deficits for facial and vocal expressions in psychopathy. Neuroscience \& Biobehavioral Reviews, 36(10), 2288-2304.

Ekman PFW, Palo Alto CA. (1976). Pictures of facial affect: Consulting Psychologist Press.

Fathi-Ashtiani A, Dastani M. (2009). Psychological tests: Personality and mental health. Tehran: Besat, 46.(In Persian)

Fertuck E A, Lenzenweger MF, Clarkin JF, Hoermann S, Stanley B. (2006). Executive neurocognition, memory systems, and borderline personality disorder. Clinical Psychology Review, 26(3), 346-375.

Grilo CM. (2004). Factor structure of DSM-IV criteria for obsessive compulsive personality disorder in patients with binge eating disorder. Acta Psychiatrica Scandinavica, 109(1), 64-69.

Jamali M, Yaghmaee F, Sabahi P, Bigdeli I. (2017). Comparing the selective attention among individuals with symptoms of antisocial personality disorder, obsessive-compulsive personality disorder and normal individuals. Joumal of Clinical Psychology, 3 .(35) (In Persian)

Jhung K, Namkoong K,Kang J, Ha RY, An SK, Kim $\mathrm{CH}$, Kim SJ. (2010). Perception bias of disgust in ambiguous facial expressions in obsessivecompulsive disorder. Psychiatry Research, 178(1), 126-131.

Kharrazi SMM,Beheshti-Zadeh M, Hashemian S. (2012). The Ability to Recognize Facial Emotional Expressions in ObsessiveCompulsive Disorder Patient and Normal Peers. Advances in Cognitive Sceince, Vol, 14, No, 2.(In Persian)

Koeda MBP, Hama T, Masuda T, Matsuura M, Okubo Y. (2013). Cross-cultural differences in the processing of non-verbal affective vocalizations by Japanese and Canadian listeners. Frontiersin Psychology Emotion Science, Volume 4, :Article 105.

Komreich C, Blairy S, Philippot P, Dan B, Foisy ML, Hess U, Verbanck P. (2001). Impaired emotional facial expression recognition in 
alcoholism compared with obsessivecompulsive disorder and normal controls. Psychiatry Research, 102(3), 235-248.

Loi F, Vaidya JG, Paradiso S. (2013). Recognition of emotion from body language among patients with unipolar depression. Psychiatry research, 209(1), 40-49.

Mannava s. (2012). Age-related Differences in Emotion Recognition Ability: Visual and Auditory Modalities. Vanderbilt University Board of Trust.Spring, Volume 8.

Marsh AA, Blair RJR. (2008). Deficits in facial affect recognition among antisocial populations: a meta-analysis. Neuroscience \& Biobehavioral Reviews, 32(3), 454465.

Mikaeili n, adineh p. (2012). The Relationship between Cognitive Functions and Theory of Mind in Obsessive-Compulsive Patients.Counseling and Psychotherapy Culture. Quarterly Joumal of the Third Year,No. 9.(In Persian)

Moosavian E, Hadian H.(2013). Investigating the role of facial emotion recognition as an independent.(In Persian)

Nejati V,Naserpur H, Zabihzadeh A, Rashidi M. (2014). A study of theory of mind and empathy in convicts of penal courts:Evidences from reading the mind test through eye image. joumal of Social Cognition, Vol. 3.No.2 .(In Persian)

Nentjes LBD, Arntz A, Breukelen G V, Slaats M. (2015). Examining the influence of psychopathy, hostility biases, and automatic processing on criminal offenders' Theory of Mind. Intemational Joumal of Law and Psychiatry,38: 92-99.

Prado CE, Treeby MS, Crowe SF. (2015). Examining relationships between facial emotion recognition, self-control and psychopathic traits in a non-clinical sample. Personality and Individual Differences, 80, 22-27.

Proctor T, Beail N. (2007). Empathy and theory of mind in offenders with intellectual disability. Journal of Intellectual and Developmental Disability, 32(2), 82-93.

Raeyat-Meoini FHH, Aghamohammadian-Sharbaf $\mathrm{H}$ R. (2014). Comparing Theory of Mind and
Executive Functions in Obsessive Compulsive Disorder. Schizophrenia, Bipolar and Normal Individuals, Vol. 6. No. 2.(22) (In Persian)

Richell R, Mitchell D, Newman C, Leonard A, BaronCohen S, Blair R .(2003). Theory of mind and psychopathy: can psychopathic individuals read the 'language of the eyes'? Neuropsychologia, 41(5), 523-526.

Robinson L, Spencer MD, Thomson L D, Sprengelmeyer R, Owens DG, Stanfield A C, McKechanie A .(2012). Facial emotion recognition in Scottish prisoners. Intemational Joumal of Law and Psychiatry, 35(1), 57-61.

Ruffman T, Halberstadt J, Murray J. (2009). Recognition of facial, auditory and bodily emotions in older adults. Joumals of Gerontology Series B: Psychological Sciences and Social Sciences, 64(6), 696-703.

Ruiz-Tagle A, Costanzo E, De Achával D, Guinjoan S. (2015). Social cognition in a clinical sample of personality disorder patients. Frontiers in psychiatry, 6, 75.

Samuels J, Nestadt G, Bienvenu OJ, Costa PT, Riddle M A, Liang KY, Cullen BA. (2000). Personality disorders and normal personality dimensions in obsessive-compulsive disorder. The British Journal of Psychiatry, 177(5), 457462.

Schimansky J, David N, Rössler W, Haker H. (2010). Sense of agency and mentalizing: dissociation of subdomains of social cognition in patients with schizophrenia. Psychiatry Research, 178(1), 39-45.

Schlegel K. (2013). Improving the measurement of emotion recognition ability. University of Geneva.

Schlegel K, Grandjean D, Scherer KR. (2014). Introducing the Geneva emotion recognition test: an example of Rasch-based test development. Psychological Assessment, 26(2), 666.

Schneider S, Christensen A, Häußinger FB,Fallgatter A J, Giese M A, Ehlis AC. (2014). Show me how you walk and I tell you how you feel - a functional near-infrared spectroscopy study on 
emotion perception based on human gait. Neuroimage, 85, 380-390.

Shekofteh s, Rafieinia p, Sabahi p. (2014). The comparison of theory of mind and facial emotion recognition in psychotic, neurotic and normal individuals. Advances in Cognitive
Science, Vol. 16, No. 1 .(In Persian)

Trotman H, McMillan A, Walker E. (2006). Cognitive function and symptoms in adolescents with schizotypal personality disorder. Schizophreniabulletin, 32(3). 